\title{
WestVirginiaUniversity
}

THE RESEARCH REPOSITORY @ WVU

Graduate Theses, Dissertations, and Problem Reports

2008

\section{The partisan politics that led to the Spanish-American War}

Donald E. Thompson Jr.

West Virginia University

Follow this and additional works at: https://researchrepository.wvu.edu/etd

\section{Recommended Citation}

Thompson, Donald E. Jr., "The partisan politics that led to the Spanish-American War" (2008). Graduate Theses, Dissertations, and Problem Reports. 774.

https://researchrepository.wvu.edu/etd/774

This Thesis is protected by copyright and/or related rights. It has been brought to you by the The Research Repository @ WVU with permission from the rights-holder(s). You are free to use this Thesis in any way that is permitted by the copyright and related rights legislation that applies to your use. For other uses you must obtain permission from the rights-holder(s) directly, unless additional rights are indicated by a Creative Commons license in the record and/ or on the work itself. This Thesis has been accepted for inclusion in WVU Graduate Theses, Dissertations, and Problem Reports collection by an authorized administrator of The Research Repository @ WVU. For more information, please contact researchrepository@mail.wvu.edu. 
The Partisan Politics that Led to the Spanish-American War

Donald E. Thompson, Jr.

Thesis submitted to the

$$
\begin{aligned}
& \text { Eberly College of Arts and Sciences } \\
& \text { at West Virginia University } \\
& \text { in partial fulfillment of the requirements } \\
& \text { for the degree of }
\end{aligned}
$$

\author{
Master of Arts \\ in \\ United States History \\ James Siekmeier, Ph.D., Chair \\ Elizabeth A. Fones-Wolf, Ph.D. \\ Joseph Hodge, Ph.D. \\ Department of History \\ Morgantown, West Virginia \\ 2008
}

Keywords: Spanish-American War, Partisan Politics, Grover Cleveland, William McKinley, Stephen Elkins, American Diplomacy

Copyright 2008 Donald E. Thompson Jr. 


\section{ABSTRACT \\ The Partisan Politics that Led to the Spanish-American War \\ Donald E. Thompson, Jr.}

This thesis explores how partisan politics played a major role in leading the United States into the Spanish-American War. With the unprecedented economic depression that began in 1893, many American politicians exploited a rebellion in Cuba to distract Americans from their own financial problems. During the administration of Grover Cleveland politicians from all political parties supported American intervention in Cuba on behalf of the rebels. This show of support for the Cuban rebels by politicians was designed to rally the American public around a common cause and highlight the difference between them and the unpopular President Cleveland who opposed American involvement in Spanish-Cuban affairs. After the election of William McKinley the Cuban rebellion became a partisan issue. McKinley, who was also opposed to American intervention in Cuba, persuaded his fellow Republican leaders to abandon their hostile stance on Spain. Democrats and Populists, on the other hand, increased their support for the Cuban rebels and used this as a political issue against McKinley and the Republicans. Facing defeat in the upcoming election, Republicans gave in to the call for war with Spain. 


\section{Table of Contents}

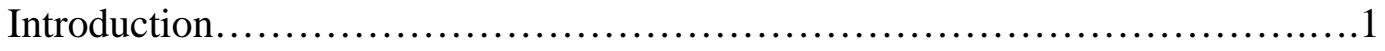

Chapter 1: American-Spanish-Cuban Relations: A Context.................... 4

Chapter 2: Cuba and the Cleveland Administration...........................16

Chapter 3: Cuba: A Political Football................................................36

Chapter 4: Run up to War.............................................49

Chapter 5: Decision for War..........................................66

Conclusion.............................................................81 


\section{INTRODUCTION}

The Spanish-American War was a dramatic turning point in the history of the United States. With a swift victory over Spain and the acquisition of an overseas empire, America assumed the role of a leading world power. The possession of territories in the Caribbean and the Pacific by the United States would drastically shape the outcome of world events in the centuries to come. As Senator Henry Cabot Lodge would proclaim a year after the cease fire, "The war of the United States with Spain was very brief. Its results were many, startling, and of world-wide meaning." ${ }^{1}$ The United States, like Great Britain, France and other European Nations had become an imperial power. On the home front, the Spanish-American War united Americans around a common enemy and helped heal wounds that had divided the country since the Civil War.

As is the case in any complex series of events, the causes of this war were numerous and inextricably intertwined. Historians have spent more than a hundred years now sorting through the evidence in search of the reasons. Traditional explanations for the war have focused on Spanish atrocities perpetrated on the Cubans, the explosion onboard the battleship Maine and "Yellow Journalism" inciting the American public. Recent emphasis has been placed on America’s imperial ambitions, economic interests, gender and cultural reasons. ${ }^{2}$ Undeniably, all of these are major

\footnotetext{
${ }^{1}$ Henry Cabot Lodge, The War with Spain, (New York, N.Y.: Harper \& Brothers, 1899), Preface.

${ }^{2}$ Walter LaFeber, The New Empire: An Interpretation of American Expansion 1860-1898. (Ithaca, New York, N.Y.: Cornell University Press, 1963); Joseph A. Fry, "Phases of Empire: Late Nineteenth-Century U.S. Foreign Relations," in The Gilded Age: Perspectives on the Origins of Modern America ed. Charles Calhoun. (Lanham, MD: Rowan \& Littlefield Publishers, Inc., 2006); John L. Offner, An Unwanted War (Chapel Hill, N.C.: University of North Carolina Press,
} 
factors to consider in any study of the Spanish-American War. However, regardless of precipitating events, the government of the United States was ultimately responsible for the decision to take the country to war. The role that partisan politics played in this decision is usually overlooked. As historian Ernest May wrote, "In no major episode of American history has so little been attributed to the intentions of political leaders and so much to forces beyond their control.”3

This study seeks to reveal the importance of partisan politics in leading the United States into a war with Spain. The thesis of this paper is that American congressmen exploited a foreign crisis in Cuba for their own political advantage. Faced with a devastating depression that was sweeping the nation, congressmen used a rebellion in Cuba to distract Americans from their own economic difficulties. At first, congressmen from all political parties took up the cause of Cuban rebels to garner public support and to highlight their differences with an unpopular Democratic President Grover Cleveland who opposed American interference in Cuban-Spanish affairs. Only after the election of Republican President William McKinley in 1896 did the Cuban rebellion become a politically partisan issue. Like Cleveland, McKinley was adamantly against involving the United States in the intrigues of Cuban affairs. McKinley opposed U.S. involvement in a war that would cost American lives, disrupt international trade and frighten the stock market. He was able to persuade Republicans in Congress to abandon their hostile stance on Spain. Congressional Democrats and Populists, on the other hand, sensed the growing public support for American intervention and were

1992), Amy S. Greenberg., Manifest Manhood and the Antebellum American Empire. (New York, NY.: Cambridge University Press, 2005)

${ }^{3}$ Ernest R. May, Imperial Democracy: The Emergence of America as a Great Power (Chicago, Il.: Imprint Publications, 1991), 251. 
determined to parlay their support for the Cuban rebels into victory in the upcoming election. Faced with potential political losses, most Republicans gave in to the demand for war and pressured McKinley to intervene in Cuba. McKinley, who had tried every means to negotiate a peaceful settlement that would bring prosperity and stability to Cuba, finally succumbed to the political pressure and declared war on Spain. In doing so, McKinley believed that he could unite the political parties behind a common cause. But this was not to be the case; as war with Spain began, political partisanship continued unabated. 


\section{Chapter One \\ American-Spanish-Cuban Relations: A Context}

Tensions had simmered between Spain and the United States over Cuba for decades. The proximity of Cuba to the states, merely ninety miles off the coast of Florida, made the island a political chess piece almost from the beginning. Thomas Jefferson considered annexing Cuba as early as 1808. In a letter to President Madison the following year, Jefferson made it clear that acquiring the "Pearl of the Antilles" was on the distant horizon but took no steps toward formal annexation. ${ }^{1}$ A common presumption among leaders of the time was that an expanding United States would inevitably pull Cuba into its orbit. John Quincy Adams expounded this theory by predicting that Cuba, "like an apple severed by the tempest from its native tree would gravitate only toward the North American Union.”’ If Adam’s words insinuated a desire for a peaceful union between Cuba and the United States, other American leaders called for a shotgun wedding. General Andrew Jackson, facing the Spanish on the Florida frontier, declared that if Congress would give him the go ahead and the equipment, "Florida shall be in possession of the United States in three months...Cuba in six."3

Although Jackson received little additional help by way of Congress, his army’s repeated excursions into Florida in pursuit of hostile Indians and runaway slaves finally forced Spain to the negotiating table. ${ }^{4}$ The resulting treaty, drawn up by President James

\footnotetext{
${ }^{1}$ U.S., Congress, Senate, Senator Call speaking for the Resolution to Recognize an Independent Cuba, S. Res. 405, 54 ${ }^{\text {th }}$ Cong., 1st sess., 4 December 1895, Congressional Record, 28: 43. ${ }^{2}$ Ibid.

${ }^{3}$ H.W. Brands, Andrew Jackson: His Life and Times. ( New York, N.Y.: Anchor Books, 2006), 348.

${ }^{4}$ Ibid.,322-331.
} 
Monroe’s Secretary of State, John Quincy Adams, required Spain to relinquish Florida to the United States and abandon their claim to the Oregon Territory. In return, the United States agreed to pay a monetary settlement and promised to respect the integrity of Spain's other territories: any plans to wrest Cuba away from Spain were put on hold. ${ }^{5}$ Spain had surrendered a large chunk of land in North America but in doing so had prevented further encroachment by the United States. With their vulnerable northern flank secure, Spain was able to pour its resources into suppressing the ongoing rebellions in its other Spanish American colonies.

The United States, meanwhile, shifted its attention to fulfilling its "Manifest Destiny” by conquering and settling the vast western region of America. The dream of a coast to coast nation had existed since the days of the Founding Fathers and was no doubt shared by the majority of Americans. The process whereby America would fulfill this dream of expansion however, was a contentious point of debate. Leaders such as Jefferson and Adams envisioned a westward expansion that would peacefully extend civilization and prosperity to those who were willing to accept a superior way of life. As Secretary of State, Adams openly criticized the idea of the United States government using force to take territory. On July 4, 1821, Adams addressed Congress to outline his vision for America; “[America] goes not abroad in search of monsters to destroy...The fundamental maxims of her policy would insensibly change from liberty to force... She

\footnotetext{
${ }^{5}$ Modern History Sourcebook: United States-Spain: Treaty of 1819. http://www.fordham.edu/halsall/mod/1819florida.html (1998).
} 
might become the dictatress of the world: she would be no longer the ruler of her own spirit.”,

Others American leaders, however, such as Jackson and his protégé James K. Polk, disagreed with Adams and saw American expansion more as a crusade. In this vision, the "Anglo-Saxon" citizens of the United States were destined to sweep aside the Native Americans and other lesser races, by force if necessary, to make way for what they viewed as their dominant culture. ${ }^{7}$ By mid nineteenth century the differences in these two visions would collide in the debate leading up to the Mexican-American War. Jackson’s Democratic Party, led by President Polk, favored forcefully taking Mexican territory while the majority of the Whig Party considered such an act unconstitutional, unnecessary and immoral. In the end, the Democrats won the debate and the United States won the war; adding more than 500,000 square miles of territory to the nation. ${ }^{8}$

With the westward push to the Pacific nearing completion, the United States once again looked south to Cuba. During the election of 1848, Democratic presidential candidate Lewis Cass made it known that if elected he would move to annex Cuba. The Democratic Party, which was becoming an ever more Southern sectional party, saw Cuba as a potential slave state that offered economical opportunities as well as free labor. No less important, adding Cuba to the slave-holding South would help swing the balance of power in Congress to their side. Northern Whig leaders understood the stakes well and decided to nominate an anti-expansionist and popular Mexican-

\footnotetext{
${ }^{6}$ John Quincy Adams., Address to Congress on the Fourth of July. (University of Missouri Digital Library), 32 http://digital.library.umsystem.edu/cgi/t/text/pagevieweridx?c=jul;cc=jul;sid=bf0307d3097042fc4028be768b1fdb12;rgn=full\%20text;idno=jul000088;vie $\mathrm{w}=$ image; $\mathbf{s e q}=1$

${ }^{7}$ Amy S. Greenberg., Manifest Manhood and the Antebellum American Empire. (New York, NY.: Cambridge University Press, 2005), 21.

${ }^{8}$ Joseph Wheelan., Invading Mexico: America's Continental Dream and the Mexican War, 18461848. (New York, N.Y.: Carroll \& Graf Publishers, 2007), 96-98, 404.
} 
American War hero; Zachary Taylor. This old general from Virginia opposed the annexation of Cuba as well as the extension of slavery into the western territories but was able to skirt these issues during the campaign and thus win the presidency. ${ }^{9}$ In Taylor's inaugural address he ignored the slavery issue altogether but made it clear that his administration would not engage in any forceful territorial expansion. He anchored his position by quoting from Washington's venerated farewell address which warned of entangling alliances with foreign nations and further declared that Christianity directed the United States to the "cultivation of peaceful and friendly relationships with all other powers." 10

Undeterred by Washington’s isolationist principles or religious constraints, some in the United States decided they would conquer foreign lands with or without the government's permission. Adventurers and soldiers of fortune organized private armies, outfitted seagoing vessels and plotted the hostile takeover of Cuba and other territories. These filibustering expeditions were frequently romanticized in American newspapers as benevolent acts of "liberation" and were bankrolled by private donations obtained through lobbying and rallies. Many political leaders also lent their support, both tacitly and openly. One of the more noteworthy series of filibustering expeditions was lead by Venezuelan native and former Cuban resident: Narciso López. Claiming to have the support of the Cuban people, López was able to recruit between 450 and 600 paid soldiers (mostly American men from the Southern states) and position them on Round Island off the coast of Mississippi in preparation for invading Cuba. President Taylor

\footnotetext{
${ }^{9}$ Amy S. Greenberg., Manifest Manhood and the Antebellum American Empire. (New York, NY.: Cambridge University Press, 2005), 34.

${ }^{10}$ James M. McPherson., To the Best of My Ability. (New York, NY.: DK Publishing Inc., 2005), 361
} 
received information about the impending expedition and ordered a naval blockade of the small island. Surrounded by the US Navy, López was forced to suspend his planned invasion of Cuba. However, López saw this defeat as only a temporary setback and within a year he would make another failed attempt to take over Cuba. Finally in August of 1851 López would make his third and last attempt on Cuba. Within two days of landing, López and his army was defeated by a combined force of Spanish regulars and armed Cuban citizens. Captured survivors, including López, were lined up in a Havana square and executed. ${ }^{11}$

The López incident and other armed forays into Cuba that originated from the United States (even though not sanctioned by the United States' government) took a huge toll on Spanish-American relations. For years, Spain had watched with alarm as more and more Americans, including political leaders, called for intervention in Cuba. Filibustering in Cuba was seen as additional proof that Americans were becoming increasingly audacious in their desire to deprive Spain of its last vestiges of empire in the New World. Spanish suspicion that the American government was complicit in these armed incursions seemed to be confirmed with the 1852 election of Democrat Franklin Pierce as president. Pierce, who was an ardent supporter of extending slavery in the western territories and beyond, did not try to hide his intention of annexing new lands. In his inaugural address he laid out his policy of expansion:

With an experience thus suggestive and cheering, the policy of my Administration will not be controlled by any timid forebodings of evil expansion. Indeed, it is not to be disguised that our attitude as a nation and our position on the globe render the acquisition of certain possessions not within our jurisdiction eminently

\footnotetext{
${ }^{11}$ Amy S. Greenberg., Manifest Manhood and the Antebellum American Empire. (New York, NY.:

Cambridge University Press, 2005), 181-183.
} 
important for our protection, if not in the future essential for the preservation of the rights of commerce and the peace of the world. ${ }^{12}$

Pierce's explicit announcement of an aggressive expansion program offended the sensibilities of those Americans who still considered the United States to be a "shinning beacon” of freedom to the rest of the world. Forcefully taking land from weaker nations was considered by many to be the ignoble occupation of European colonizers or Oriental despots: the United States was founded on higher moral principles. Nonetheless, within a year of taking office, the Pierce administration had persuaded Mexico, by threat of force, to sell the United States another significant portion of its northern territory. Called the "Gadsden Purchase” after the American ambassador to Mexico, James Gadsden, who negotiated the treaty, this treaty added an additional 45,535 square miles to the American southwest. ${ }^{13}$

Buttressed by this diplomatic victory, President Pierce would next turn his attention to an international dilemma that was brewing in Cuba. In February of 1854, Spanish authorities seized a United States’ merchant ship Black Warrior in Havana harbor for failure to provide the proper shipping documentation. Painted as a brazen act of Spanish thievery by American newspapers, the ship’s confiscation touched off a public clamor for war with Spain. ${ }^{14}$ President Pierce quickly sent word to his American minister at Madrid, Pierre Soule, to deliver the Spanish an explicit ultimatum- Spain had forty-eight hours to pay an indemnity of three hundred thousand dollars. ${ }^{15}$

\footnotetext{
${ }^{12}$ Franklin Nichols., Franklin Pierce: Young Hickory of the Granite Hills. (Philadelphia, PA.: University of Pennsylvania Press, 1969) 235.

${ }^{13}$ Ibid., 266. and Amy S. Greenberg., Manifest Manhood and the Antebellum American Empire. (New York, NY.: Cambridge University Press, 2005), 36.

14 "Detention and Abandonment of the Black Warrior" New York Times, 10 March 1854, p. 1.

${ }^{15}$ Franklin Nichols., Franklin Pierce: Young Hickory of the Granite Hills. (Philadelphia, PA.: University of Pennsylvania Press, 1969) 328-329.
} 
At the brink of war, Secretary of State William Marcy stepped in and offered the Spanish more moderate demands that opened the way for negotiations. ${ }^{16}$ Spain was notorious for "foot-dragging" in any diplomatic bartering with the United States and this time would be no exception. An impatient Pierce soon grew frustrated with what he perceived as stalling by Spain and decided to use the same strong-arm tactics that had succeeded in Mexico. He directed Minister Soule to confer with the American Ministers to France and England in order to devise a plan to take Cuba from Spain. This plan, which would be called the "Ostend Manifesto" after the town in Belgium where the three ministers wrote it, declared; "Cuba is as necessary to the North American republic as any of its present members.” Furthermore, the ministers recommended offering Spain one hundred and twenty million dollars for the island. If this offer were rejected then the United States would be "justified" in taking Cuba by force. ${ }^{17}$

Although this document was sent to the State Department as a confidential dispatch, word of its content was soon leaked to American newspapers. A fickle American public that had condoned or tolerated annexing Mexican territory months earlier in the Gadsden Purchase reacted differently to this blatant land grab in the Caribbean. Many Americans, especially anti-slavery Northerners, denounced this plan as a government-sanctioned act of piracy. Bending to the public backlash, President Pierce disavowed the document and accepted Minister Soule's resignation. ${ }^{18}$ Pierce's dream of extending the American empire beyond the shoreline had been strangled in its cradle. Even so, one of the Ostend Manifesto's authors, former minister to England, James

\footnotetext{
${ }^{16}$ Ibid., 330.

${ }^{17}$ Ibid., 367-371

${ }^{18}$ Amy S. Greenberg., Manifest Manhood and the Antebellum American Empire. (New York, NY.: Cambridge University Press, 2005), 36-38.
} 
Buchanan, would be elected the next president. Like Pierce, Buchanan was a proexpansionist; but tensions between the North and South over the slavery issue would eclipse all international concerns during his term in office. Before Buchanan was out of office seven Southern states would secede from the union and the incoming (and first) Republican President, Abraham Lincoln, would confront a bloody civil war that threatened the existence of the United States.

With the United States occupied with a civil war, Spain took the opportunity to send its military to the Caribbean once again to re-occupy the island nation of Santo Domingo. Pedro Santana, the Dominican president, had requested Spanish intervention but the citizens of the island soon rebelled and within two years the Spanish were forced to annul the annexation. Although the rebellion succeeded in permanently expelling Spain from Santo Domingo, the financial costs of waging war bankrupted the small nation's weak economy. In 1869, drowning in debt, the new government of Santo Domingo decided to negotiate a treaty for the annexation of their country to the United States for one and a half million dollars. The current President of the United States, Ulysses S. Grant, was dealing with the aftermath of his own war yet nevertheless was enthusiastic about the prospect of buying a foothold in the Caribbean. The Congress, however, was less excited about obtaining a troubled island nation that presented all sorts of potential problems. After a lengthy consideration in the Senate the treaty was ten votes short of ratification. ${ }^{19}$

This debate over annexing Santo Domingo foreshadowed the anti-imperialism arguments that would be heard in the wake of the Spanish-American war. Those

\footnotetext{
${ }^{19}$ Allan Nevins., Hamilton Fish: The Inner History of the Grant Administration (Binghamton, N.Y.: Vail-Ballou, Inc., 1936), 249-278.
} 
Republicans who opposed the treaty argued that it was unconstitutional to annex nonadjacent mainland territory. Republicans, such as the reformer, Carl Schurz, also argued that the non-white peoples of the Caribbean were unfit for a democratic government and would become a burden on the country. Democrats, who held only twelve seats in the Senate, also argued against the treaty on racial grounds: Santo Domingo would become a "black state" whose citizens would gain voting rights and a free pass to migrate to the continental United States. ${ }^{20}$ Besides the race issue, Democrats were also wary of any foreign adventure or territorial conquest that might potentially strengthen the federal government or increase the import of agricultural products that could compete with their own local produce. ${ }^{21}$ This, of course, was a complete reversal of their antebellum support for conquering new territory.

Spain had likewise opposed the treaty that would have given its former colony to the United States. Among many reasons, Spain feared the United States would be tempted to annex Cuba next. Unrest on Cuba had indeed escalated into open warfare by 1868 and the American public was watching closely as the war unfolded. President Ulysses S. Grant's administration did not support either side in the conflict but many private filibuster expeditions launched from the United States began shipping arms and other supplies to the Cuban rebels. As before, these filibusters were often given a wink and a nod by local officials and celebrated in newspapers. ${ }^{22}$

\footnotetext{
${ }^{20}$ Ibid., 316-321.

${ }^{21}$ Joseph A. Fry, "Phases of Empire: Late Nineteenth-Century U.S. Foreign Relations," in The Gilded Age: Perspectives on the Origins of Modern America ed. Charles Calhoun. (Lanham, MD: Rowan \& Littlefield Publishers, Inc., 2006), 312.

${ }^{22}$ Allan Nevins., Hamilton Fish: The Inner History of the Grant Administration (Binghamton, N.Y.: Vail-Ballou, Inc., 1936), 176-180.
} 
On October 31, 1873 a Cuban gunrunning boat named the Virginius, captained by a former American naval officer Joseph Fry and falsely flying a United States flag, was captured by the Spanish off the coast of Jamaica. The ship’s contents of arms and ammunition were confiscated and the captain and crew were taken back to Cuba for trial. Despite an outcry of international condemnation, Fry and fifty three of his men and passengers were found guilty of piracy and executed. ${ }^{23}$ American newspapers reported that several of the sailors were decapitated and their heads placed on pikes and marched through the streets. An outraged American public once again called for military action against Spain. ${ }^{24}$

President Grant responded with sympathy for the executed Americans but was not prepared to take military action against Spain. The United States army was still overseeing reconstruction in the South and was ill-prepared to begin a foreign conflict over dubious reasons. ${ }^{25}$ Besides, President Grant was also coping with a deep economic depression in the United States and was reluctant to add to the mounting national debt. Spain also signaled a willingness to make amends for the Virginius incident and began working out an agreement with Secretary of State Hamilton Fish to pay an indemnity to the families of the executed sailors. In addition, the Spanish government agreed to surrender the Virginius and the surviving crew and passengers to an American warship and salute the American flag. During the negotiations Grant also offered to purchase the

\footnotetext{
23 “The Virginius,” New York Times, 7 November 1873, p. 7.

24 "Reported Barbarities of the Spaniards- The Head of the Executed Carried on Pikes" New York Times, 18 November 1873, p. 1.

${ }^{25}$ U.S., Congress, House, Congressman Mason speaking on Senate Resolution to provide for the Twelfth and subsequent census, S. Res. 94, 55th Cong., 2d sess., 9 February 1898, Congressional Record, , 31: 1580.
} 
troubled island from Spain. ${ }^{26}$ The offer was rejected by Spanish officials and afterwards, Secretary Fish maneuvered to stall any further attempts by the government to annex Cuba. ${ }^{27}$ Fish's opposition to making Cuba a state mirrored the racial arguments heard in the debates over acquiring Santo Domingo. ${ }^{28}$

While American and Spanish leaders debated the fate of Cuba, the rebels continued their war for independence. For ten years the rebels struggled persistently yet unsuccessfully against a superior Spanish army. The rebellion finally ended in 1878 after Spain promised a series of limited political reforms. Negotiating out of necessity and with limited help from abroad, the beleaguered rebels accepted the Spanish terms. Unfortunately, the promised reforms never fully materialized and life improved little for the inhabitants of the island.

Dismayed at the lack of reforms, thousands of these war-weary Cubans made their way to the United States and began rebuilding their lives. Many still harbored the dream of an independent homeland but understood the need to have American support in any future attempt at revolution. Cuban expatriate leaders, many whom were veterans of the late war, began working within the Cuban communities across America to enlist members and collect funds and supplies for a second revolution. These revolutionary leaders also created a lobbyist organization, known as the "Cuban Junta" that worked to gain support from American politicians, newspapers and the public for liberating

\footnotetext{
${ }^{26}$ Allan Nevins., Hamilton Fish: The Inner History of the Grant Administration. (Binghamton, N.Y.: Vail-Ballou, Inc., 1936), 687, 192-193.

${ }^{27}$ Ibid., Ironically, it would be Fish's grandson and namesake who would become the first American soldier killed in the Spanish-American War.

${ }^{28}$ Walter LaFeber, The New Empire: An Interpretation of American Expansion 1860-1898. (Ithaca, New York, N.Y.: Cornell University Press, 1963), 32.
} 
Cuba. ${ }^{29}$ Even though the Junta was partially successful in this effort, the American government was not yet ready to take up the cause of "Cuba Libre.” Cubans would have to wait until the end of the nineteenth century before the foreign policy of the United States would shift in their favor.

${ }^{29}$ G.J.A. O’Toole, The Spanish War: An American Epic 1898. (New York, NY., W.W. Norton \& Company Inc, 1984), 47-49. 


\section{Chapter Two}

\section{Cuba and the Cleveland Administration}

During the 1890s American foreign policy would transition from a Western-hemisphere focused policy and restrained post-bellum attitude to a more aggressive global strategy. Prompting this policy shift were the rapidly changing economical realities of the late nineteenth century. The United States had emerged during this period as one of the world's leading industrial nation and foreign markets were becoming increasingly important for continued growth. ${ }^{1}$ In order to open up these new markets for trade the United States had to reach out and engage the world as never before. This unprecedented assertion into global affairs would present many new challenges to American leaders and breathe new life into the perennial debate over territorial expansion.

Many, if not most, of America's leaders at this time favored a foreign policy that promoted a “commercial expansion” whereby the United States would access global markets through such benign methods as reciprocal trade agreements and leasing foreign coaling stations. ${ }^{2}$ A new generation of leaders, however, believed that the United States' new position as a world power required a more aggressive policy toward its global neighbors. These leaders, such as Henry Cabot Lodge and Theodore Roosevelt, were part of an imperialist movement that called for the United States to abandon its restrained foreign

${ }^{1}$ H.W. Brands, The Reckless Decade: America in the 1890s (Chicago, Il.:The University of Chicago Press, Ltd., 1995), 39.

${ }^{2}$ William McKinley's Address to the National Association of Manufacturers, 27 January 1898, McKinley Papers, Reel 60.; Amy S. Greenberg., Manifest Manhood and the Antebellum American Empire. (New York, NY.: Cambridge University Press, 2005), 17. 
policy and compete with the European powers in territorial conquests. ${ }^{3}$ Evidence that this movement was gaining influence came in January of 1893 when a group of American and European citizens, with the help of U.S. Marines, overthrew the queen of Hawaii and established a provisional government on the Central Pacific islands. Afterwards they began negotiations to be annexed to the United States. ${ }^{4}$ President Benjamin Harrison accepted the request but his term in office expired before he could push the treaty through Congress. The incoming Democratic President, Grover Cleveland immediately withdrew the treaty after taking office. ${ }^{5}$ President Cleveland had defeated Harrison in the election of 1892 mainly by promising lower tariffs and other governmental reforms but was also notoriously opposed to territorial expansion or any semblance of imperialism. Cleveland was determined to maintain a cautious and conservative foreign policy much like Washington had envisioned in his celebrated farewell address.

However, soon after Cleveland took office an economic crisis overshadowed all international concerns. This financial disaster, later called the "Panic of 1893," would develop into the worst economic depression in the country's history to that point.

Historians and economists offer many different theories on what exactly caused the depression but most agree that the Sherman Silver Purchase Act of 1890 greatly exacerbated the problem. This act, designed to support Western silver mining interests, mandated the U.S. Treasury buy a certain amount of silver each month with bank notes that could be redeemed for either silver or gold.

\footnotetext{
${ }^{3}$ Carl Schurz. “The New Imperialists,” North American Review, September 1898, p.32.

4“A Revolution In Hawaii,” New York Times, 29 January 1893, p. 1.

5 “The Treaty Withdrawn,” New York Times, 10 March 1893, p. 5.
} 
During the panic numerous investors rushed to cash in their silver notes for gold, thus depleting the federal gold reserves. Cleveland had strongly opposed the Sherman Silver Purchase Act even before it was enacted but was nonetheless blamed for the resulting economic storm. ${ }^{6}$ Reacting promptly, Cleveland called for an emergency congressional session to repel the act. The measure passed but the economic freefall continued.

In the wake of the Panic of 1893 thousands of companies across America went out of business, farmers were devastated by falling crop prices, numerous railroads went bankrupt, and more than six hundred banks closed. ${ }^{7}$ The unemployment rate soared to between twelve and eighteen percent and many workers who remained employed saw their wages cut drastically. ${ }^{8}$ Production of bituminous coal almost completely halted when one hundred and eighty thousand miners went on strike. ${ }^{9}$ This unprecedented instability in American society caused public confusion and disillusionment in national leaders.

The nation appeared to be on the verge of an open insurrection by March of 1894 when a populist leader, Jacob S. Coxey, organized hundreds of unemployed workers from Ohio and Pennsylvania into an "army" and set out on a peaceful march to Washington D.C. to demand federal relief. Passing through towns on its way east, Coxey’s army was met by thousands of cheering well wishers who lined

\footnotetext{
${ }^{6}$ James M. McPherson, To the Best of My Ability (London, U.K.: DK Publishing Inc, 2004), p. 165. In the same way Herbert Hoover would be held responsible for the Great Depression of the 1930s, Cleveland became the face of the Panic of 1893. ${ }^{7}$ Ibid.

${ }^{8}$ Christina. Romer, “Spurious Volatility in Historical Unemployment Data.” Journal of Political Economy, 19 (November 1986), 1-37.

${ }^{9}$ Almont Lindsey, The Pullman Strike (Chicago, Il.: University of Chicago Press, 1942), 14-15.
} 
the streets to witness the spectacle. ${ }^{10}$ Following in Coxey's footsteps, thousands of more citizens from around the country formed into their own battalions to advance on the capital. This mass movement turned into chaos as several of these Coxey-type armies seized freight trains and rioted in the streets. ${ }^{11}$

Newspapers generally downplayed the seriousness of these armies, portraying the marchers as bands of tramps and cranks more concerned with begging for hand-outs than fomenting a revolution. Some in the press, however, saw the Coxey movement as symptomatic of a growing problem. The Economist newspaper reported that "The greatest industrial struggle ever begun in this country, if not in the world, is in progress here."12 The London Chronicle similarly predicted that "coxeyism” would eventually escalate into a full blown civil war that would be "almost as serious as that which arose from slavery."13

Meeting these challenges vigorously, the Cleveland Administration dispatched federal troops to no less than fourteen states to assist local authorities in confronting the marchers. In the capital, the War Department delivered hundreds of small arms and repeating rifles to the Treasury Department in anticipation of Coxey's arrival. The local police force also beefed up their patrols and began arresting suspicious-looking strangers. ${ }^{14}$ Members of Congress were divided over how to respond to the approaching armies. Many congressmen, especially from the Western states, expressed support for these unemployed

\footnotetext{
10 “Coxey’s Army on the Move,” New York Times, 25 March 1894, p. 1.

11 "Large Army to Leave Chicago,” New York Times, 25 April 1894, p. 1.

${ }^{12}$ Walter LaFeber, The New Empire: An Interpretation of American Expansion 1860-1898. (Ithaca, New York, N.Y.: Cornell University Press, 1963), 174.

13 “London Comments on Coxeyism,” New York Times, 25 April 1894, p. 1.

14 “Vanguard Near Washington," New York Times, 25 April 1894, p. 1.
} 
workers whom they believed had full entitlement to stage peaceful demonstrations. Other congressmen predicted the Coxey movement was destined to descend into chaos and widespread bloodshed. Nevada Republican William M. Stewart wrote to Coxey to implore him to suspend his march and instead express his grievances with a ballot in the upcoming November election. Stewart cautioned Coxey that marching on Washington would only give President Cleveland a pretext to strengthen the federal government and suppress other oppositional voices. ${ }^{15}$

Undeterred by any warnings, Coxey and his army finally arrived in Washington D.C. on May $1^{\text {st }} 1894$. Forming a flamboyant parade, complete with banners and a brass band, Coxey’s followers marched down Pennsylvania Avenue to the capitol building. As thousands of spectators crowded to witness the scene, Coxey was arrested and hustled off without much resistance. The rest of his followers were likewise arrested or dispersed by club-wielding policemen. ${ }^{16}$ The other industrial armies around the country met similar fates as federal troops apprehended their leaders and forced the demonstrators to disband.

Less than two weeks after Coxey's arrest, three thousand workers at the Pullman Palace Car Company in Illinois went on strike. ${ }^{17}$ The American Railway Union, lead by Eugene V. Debs, supported the strike and organized a nation-wide boycott of trains hauling Pullman cars and effectively closed down all traffic

\footnotetext{
${ }^{15}$ Vincent, Hnery., Mass Violence in America: The Story of the Commonweal. (NY, New York.:Arno Press Inc., 1969), 58-60.

16 “Coxey Silenced By Police,” New York Times, 2 May 1894, p. 1.

17“Pullman Car Company’s Men Strike,” New York Times, 12 May 1894, p. 8.
} 
west of Chicago. ${ }^{18}$ President Cleveland once again reacted forcefully by ordering Federal Marshals and some twelve thousand United States Army troops to break up the strikes and restore service to the railroads. These heavy-handed tactics of Cleveland caused an outrage among much of the American public. Politically savvy Republicans, Populists and Democrats denounced these drastic measures and scrambled to distance themselves from the President. ${ }^{19}$

Unfortunately for the Democrats, the public's anger at Cleveland and the continued economic crisis manifested itself in the off-year election of 1894 as voters turned strongly against them. Suffering the worst defeat in their history, the Democratic Party lost every congressional race outside the South. Prior to this election, the Democrats had enjoyed a majority in the House and Senate, now they had lost both. In the House alone they gave up one hundred and twenty-five seats and were now the minority with only ninety three members as opposed to two hundred and fifty-four Republicans. ${ }^{20}$ Faced with these unprecedented electoral losses, the Democratic Party struggled to maintain itself as a viable political force. Experienced Democratic politicians understood that if the party were to succeed in the future it needed to focus on popular issues that would attract former Democratic voters back into the fold. One issue that had historically proven successful in rallying the public behind their leaders and distracting them from domestic problems was a foreign crisis. Evidence that some political strategists were weighing the benefits of a foreign crisis can be found in the words of one prominent Democrat, Fitzhugh Lee, who advised

\footnotetext{
${ }^{18}$ Almont Lindsey, The Pullman Strike (Chicago, Il.: University of Chicago Press, 1942), 130.

${ }^{19}$ James M. McPherson, To the Best of My Ability (London, U.K.: DK Publishing Inc, 2004), 164.

20 “Next Congress Republican,” New York Times, 7 November 1894, p. 1.
} 
Cleveland; "(war) might do much toward directing the minds of the people away from imaginary ills. ${ }^{21}$ Nonetheless, Cleveland stubbornly refused to fall prey to the siren song of jingoism.

However, the opportunity for Congress to exploit an international crisis would come in early 1895 when war once again broke out in Cuba. This renewed war for independence, like the Democrat's political headaches, stemmed from the financial meltdown in the United States. Thousands of Cuban émigrés in New York and Florida had lost their jobs after the Panic of 1893 and these idle workers were recruited by the Cuban Junta to form a new revolutionary army and return to their homeland. Also, the American depression had severely inflicted the Cuban economy and poverty-stricken citizens on the island were ready for a revolution. The first battle of the "Cuban War for Independence” occurred in February 24, 1895 when a small band of Cuban rebels attacked a detachment of Spanish soldiers in the village of Baire, Cuba. This minor skirmish in the Cuban jungle was a military defeat for the out-gunned rebels but it succeeded in arousing the excitement of politicians in Washington, D.C.

The next day, members of the United States' Senate offered their support for Cuban liberation and Florida Democratic Senator Wilkinson Call submitted a resolution demanding the Spanish government release a captured rebel, Antonio Maximo Mora, who held American as well as Cuban citizenship. ${ }^{22}$ In an age when international communication systems were relatively limited and erratic, it is remarkable that details

\footnotetext{
${ }^{21}$ Walter Karp, The Politics of War (New York, N.Y.: Harper \& Row, 1979), 36.

${ }^{22}$ U.S., Congress, Senate, Congressional Record, 53rd Cong., 2nd sess., 1895, 27, pt. 3: 2722.
} 
of this first battle, in a small Cuban village, could reach Washington D.C. so quickly. ${ }^{23}$ The prompt transmission of this information can be credited to the efficiency of the Cuban Junta which was working closely with some members of Congress. Senator Call, who had submitted this first resolution, had especially close ties with the Junta. His state of Florida was home to many Cuban-Americans and his son was employed by the Junta to raise funds for their cause. ${ }^{24}$

Later that week, as hostilities on the island increased, the Senate discussed Spanish brutalities against innocent civilians and submitted legislation to the Committee on Foreign Relations that condemned Spanish authorities for imprisoning two more Cuban citizens holding American passports. ${ }^{25}$ The following month another incident occurred in Cuban waters that electrified members of Congress. The Spanish navy, on patrol for gunrunners, fired a warning shot over the bow of an American mail ship, the Alliança, that was steaming off the eastern coast of Cuba. ${ }^{26}$ Infuriated congressmen took the podium once again to rebuke the "treacherous Spaniards" for this attack on innocent Americans. Democrat Senator from Alabama, John T. Morgan demanded President Cleveland to “...dispatch a fleet of warships to Havana.” Continuing the war cry, Republican Shelby Cullom of Illinois angrily proclaimed "it is time someone woke up and realized the necessity of annexing more property.” The New York Tribune reported the next day “The outrage (by Senators) would not have been more flagrant if

\footnotetext{
${ }^{23}$ The telegraph was the fastest medium available at this time. Several telegraph cables linked Cuba with Spain, the United States and other Caribbean islands. But, Cuban cable stations, located in the largest cities and near the shore, were usually controlled by Spanish authorities.

${ }^{24}$ Ernest R. May, Imperial Democracy: The Emergence of America as a Great Power (Chicago, Il.: Imprint Publications, 1991), 74.

${ }^{25}$ U.S., Congress, Senate, Congressional Record, 53rd Cong., 3rd sess., 1895, 27, pt. 4: 3039.

26 “Fired On A Mail Ship,” New York Times, 13 March 1895, p. 1.
} 
they (the Spanish) had entered the harbor of New York and bombarded the City Hall.”27 Indeed, this early saber-rattling by members of both major parties in the United States was an overreaction but would be characteristic of the dialogue in Congress for the next several years.

Contrary to the stir in Congress, the major newspapers in America gave little attention to this new outbreak of rebellion in Cuba. The New York Times reported on page five that a revolution in Cuba was a "matter of fiction," and that the incident in the village of Baire was nothing more than "rioters" who wished to complain to the local governor. ${ }^{28}$ Other media outlets depicted the rebellion as just another in a long line of periodic revolts. ${ }^{29}$ This disputes the myth that aggressive congressmen were only reacting to pressure from sensationalist newspapers' accounts of the Spanish atrocities in Cuba. An explanation that is now routinely offered by historians is that competition between newspapers, William Randolph Hearst’s Journal and Joseph Pulitzer’ World in particular, caused the Spanish-American war. Often quoted is Hearst's telegraph to Cuban correspondent Frederic Remington; "You furnish the pictures and I'll furnish the war.”30 The fact is- Hearst did not begin publishing the Journal until seven months after the rebellion began. Likewise, Pulitzer’s World did not print its first insurgentsympathetic editorial until nearly a month after the first anti-Spanish discourse in Congress. In this era, the majority of newspapers in the United States were mouthpieces for one political party or another. These papers were no exception. Pulitzer and Hearst

\footnotetext{
${ }^{27}$ Walter Karp, The Politics of War (New York, N.Y.: Harper \& Row, 1979), 41-42.

28 "Cuba's Alleged Revolution,” New York Times, 27 February 1895, p. 5., “Cuban Rebels Penitent,” New York Times, 28 February 1895, p.5.

${ }^{29}$ Kristin L. Hoganson, Fighting for American Manhood: How Gender Politics Provoked the Spanish-American and Philippine-American Wars (New Haven, CT.: Yale University Press, 1998), 2.

${ }^{30}$ Donald H. Dyal, Historical Dictionary of the Spanish American War (Westport, CT.: Greenwood Publishing Group, Inc., 1996), 157.
} 
were both well-known supporters of Democratic causes. Hearst was the son a

Democratic Congressman and would later parlay his fame as a newspaper editor into his own political career. ${ }^{31}$ It is certain, however, that horrific accounts of atrocities in Cuba contributed to an increase in newspaper sales, but many of these headlines were provided by the politicians themselves.

In the weeks after the Alliança affair, Congressmen continued to speak out in condemnation of Spain. In several states, Congressmen organized mass rallies and patriotic fundraisers in honor of the Cuban rebels. ${ }^{32}$ President Cleveland, who was a stubborn enemy of jingoism, watched the antics of these leaders with growing alarm. ${ }^{33}$ In a stern address to Congress, the President stressed the obligation of the United States government to recognize Spanish sovereignty in Cuba and condemned filibustering expeditions originating from the United States. ${ }^{34}$ In regards to the Alliança incident, Cleveland made it clear that he intended to give the Spanish government sufficient time to apologize and did not want to provoke them unnecessarily. ${ }^{35}$ To Spain, Cleveland sent word via Secretary of State Walter Q. Gresham to demand of the government “...a prompt disavowal of the unauthorized act and due expression of regret” and warned that future interference with American shipping would not be tolerated. ${ }^{36}$

As Cleveland waited for his demands to be met, another Latin American crisis took center stage in America. This dispute concerned the border region between

\footnotetext{
${ }^{31}$ W.A. Swanberg, Pulitzer (New York, N.Y.: Charles Scribner's Sons, 1967), 224-225.

32 "Frye Wants A War With Spain,” New York Times, 21 March 1895, p. 2., "Americans Who Favor Revolt,” New York Times, 6 April 1895, p. 5., “Chicago’s Cubans Contribute,” New York Times, 9 April 1895, p. 5.

${ }^{33}$ Richard E. Welch, The Presidencies of Grover Cleveland (Lawrence, KS.: University Press of Kansas, 1988), 195.

${ }^{34}$ U.S., Congress, Senate, Congressional Record, 54th Cong., 1st sess., 1895, 28, pt. 1: 11.

35 "Leniency Toward Spain,” New York Times, 23 March 1895, p. 1.

${ }^{36}$ U.S., Department of State, Foreign Relations of The United States, Government Documents Series, no. 392480 (1895), part 2, p. 1177.
} 
Venezuela and British Guyana in South America. The disagreement stemmed from the discovery of gold in this area (and control of the Orinoco River, gateway to South America) and leaders of both countries claimed to own the territory. Worried that the superior British military was poised to seize the land, Venezuela petitioned the United States for assistance on the grounds that this was a violation of the Monroe Doctrine. Venezuelan Minister of Foreign Relations, P. Ezequiel Rojas sent word to Secretary of State Walter Gresham that his country regarded the United States as "a nation that is called upon to watch over the political and territorial integrity of the other American peoples. ${ }^{37}$ This Venezuelan recognition of the Monroe Doctrine was considered by many as further evidence of American hegemony in the Western Hemisphere. In a widely-read article, Republican Senator Henry Cabot Lodge of Massachusetts condemned the "territorial aggression" of the British and reminded the government of its responsibility to prevent European imperialism in Latin America. ${ }^{38}$

Members of Congress salivated over this opportunity to stir up Americans' latent animosity toward its old nemesis; Great Britain. The well-regarded North American Review reported that Democrats had been eager to use the Venezuelan border dispute as a "new plank for their national platform" and the Republican Party likewise "derived its fair share of public approbation from the incident.”39 Texas Democratic Congressman Thomas Paschal was even more candid in his appraisal of the possible political benefits of this crisis; "Turn this Venezuelan question up or down, North, South, East or West,

\footnotetext{
${ }^{37}$ U.S., Department of State, Foreign Relations of The United States, Government Documents Series, no. 804 (1895), part 2, p. 1475.

38 "England, Venezuela and the Monroe Doctrine,” The North American Review, June 1895, p. 653. See also Walter LaFeber, "Evolution of the Monroe Doctrine from Monroe to Reagan," in Lloyd Gardner ed., Redefining the Past: Essays in Diplomatic History in Honor of William Appleman Williams,(Corvallis: Oregon St. University Press, 1986) 121-141.

39 "Congress and its Critics," The North American Review, March 1896, Vol. 162., Iss. 472., p.372.
} 
and it's a winner," he confessed to the newly-appointed Secretary of State, Richard Olney. ${ }^{40}$ Continuing, Paschal compared anarchists, socialists and populists to an outbreak of boils on the "political surface” of America and exclaimed "One cannon shot across the bow of a British boat in defense of this principle [the Monroe Doctrine] will knock more pus out of it than would suffice to inoculate and corrupt our people for the next two years. ${ }^{41}$ In another letter to Olney, George P. Ikirt, the campaign manager of the Ohio Democratic gubernatorial nominee, pleaded for “a little jingo” against Great Britain to help turn out the vote for his candidate in the upcoming election. ${ }^{42}$

To the surprise of many, President Cleveland agreed to confront Great Britain. Without consulting Venezuela, Cleveland directed Secretary of State Olney to send a strongly-worded message to the British demanding they submit to American arbitration. When the British initially refused to comply, Cleveland asked Congress for authorization to appoint a boundary commission and proposed that the commission's findings be enforced "by every means." This thinly-veiled threat of war against one of the greatest military superpowers in the world quickly became the hot topic of national and international newspapers. ${ }^{43}$ Congress unanimously passed the measure and Olney sent another letter to the British reiterating America’s firm stance. ${ }^{44}$ British leaders cautiously studied their options and decided against creating another enemy at this precarious juncture. Faced with numerous difficulties in managing their global empire

\footnotetext{
${ }^{40}$ H. W. Brands, The Reckless Decade: America in the 1890s (Chicago, Ill.: University of Chicago Press, 1995) , 299. Olney had replaced Former Secretary of State Walter Q. Gresham who had died suddenly on May $28^{\text {th }} 1895$.

${ }^{41}$ Ibid., p. 299.

42 Ernest R. May, Imperial Democracy: The Emergence of America as a Great Power (Chicago, Il.: Imprint Publications, 1991), 33.

43 “Ministers Deprecate the Talk About Prospective War,” New York Times, 23 December 1895, p. 9.

${ }^{44} \mathrm{Mr}$. Olney to Mr. Bayard., U.S., Department of State, Foreign Relations of The United States, Government Documents Series, no. 804 (1895), part 2, pp. 545-562.
} 
and the growing threat from Germany, Britain reluctantly accepted American arbitration in the border dispute and tensions eased. ${ }^{45}$

President Cleveland had temporarily won the approval of the American public and politicians. Letters filled with congratulation and patriotic passion flooded the Executive Mansion. Theodore Roosevelt, currently serving as President of the New York City Police Commissioners, wrote Cleveland to thank him “with all my heart as an American,” for his success in Venezuela. ${ }^{46}$ Some historians, such as Walter Karp, believe this episode in foreign diplomacy proved Cleveland had succumbed to political pressures and was trying to garner the people's support by taking a firm position against the British. ${ }^{47}$ Yet, a close study of Cleveland's prior opposition to any form of imperialism, demonstrates this stance on the Venezuelan border issue followed precedent. For Cleveland, the British threat of taking Venezuelan land by force did indeed represent a violation of the Monroe Doctrine; to ignore this affront would be a sign of American weakness. Cleveland was also well aware that European countries had recently contemplated expanding their imperial empires into Latin America. ${ }^{48}$ In his Annual Address, Cleveland pointed out past incursions by European powers into Latin America and suggested that the threat of additional territorial expansion was becoming

\footnotetext{
${ }^{45}$ Ernest R. May, Imperial Democracy: The Emergence of America as a Great Power (Chicago, Il.: Imprint Publications, 1991), 40-41. Despite their exclusion from the decision-making process, Venezuelan leaders were enthusiastic about the United States' arbitration. However, the Boundary Commission's final report had mixed results for the South American country: Venezuela, in the end, lost some 30,000 square miles to British Guyana.

${ }^{46}$ Roosevelt to Cleveland, February13, 1896, Cleveland Papers, Reel 92, 32879-32880.

${ }^{47}$ Walter Karp, The Politics of War (New York, N.Y.: Harper \& Row, 1979), 36-37.

48 “Monroe’s Real Doctrine,” New York Times, 22 April 1895, p. 1.
} 
ever more tempting to imperialist nations. ${ }^{49}$ This strong stance against British aggression in Venezuela would be a powerful warning to all the European powers.

Regardless of Cleveland's motivation, many members of Congress interpreted this diplomatic victory as proof that America had entered the pantheon of great nations. Reveling in its success, Congress reconvened in December with a renewed confidence in the United States’ ability to facilitate Cuban independence. Several resolutions addressing the Cuban question were submitted to the House Foreign Affairs and the Senate Foreign Relations Committee for consideration. The first to make it to the full Senate on January 28, 1896 was a resolution by Democrat Senator John T. Morgan that granted belligerent rights to the Cuban insurgents. The second resolution to be debated, offered by Republican Senator Don Cameron, requested the President to work with Spain "...for the recognition of the independence of Cuba. ${ }^{, 50}$ Both of these measures, which were later combined as the Morgan-Cameron resolution, were concurrent or "non-binding” and required no executive action.

Amid the deliberation on these resolutions, a series of events in Cuba intensified the debate. First, the infamous Captain-General Valeriano Weyler replaced the ineffective Spanish head of the military forces in Cuba, General Arsenio Martínez Campos. Already well known in the United States for his brutal military tactics during the Ten Year War, Weyler was given full power by the Spanish government to take whatever drastic measures were necessary to quash the rebellion. ${ }^{51}$ Weyler, dubbed "The Butcher," and the "modern imitator of Cortez" by newspaper reporters, would soon live

\footnotetext{
${ }^{49}$ Cleveland's Annual Address., U.S., Department of State, Foreign Relations of The United States, Government Documents Series, no. 804 (1895), part 2, pp. 542-545.

${ }^{50}$ U.S., Congress, Senate, Congressional Record, 54th Cong., 1st sess., 1896, 28, pt. 2: 2294.

51 “Cruelties For Cubans,” New York Times, 19 January 1896, p. 16.
} 
up to his nickname. He began a program of forced concentration (called

"reconcentrado" by insurgents and the American press) whereby four hundred thousand men, women and children would eventually be herded together into camps lacking proper sanitation and provisions. Consequently, thousands of Cuban civilians began dying of starvation and disease..$^{52}$

After word of Weyler's arrival reached Washington, congressional debate on the Morgan-Cameron Resolution focused on the brutality of the Spanish military and the need to protect American citizens and property in Cuba. Displaying patriotic fervor, proponents of the resolution argued for the use of the American military to end these atrocities in Cuba and force Spain out of the Western Hemisphere. One exceptional exhibition of political theater by Democrat Senator, Roger Q. Mills of Texas, was featured in the next edition of the New York Times. The heading for the story was "Mills Shouts For War: The Excited Texan Calls For Armed Intervention In Cuba.” The story in part read; "Mr. Mills grabbed a sword... and began to strike down on the oppressors of Cuba regardless of consequences to himself, without pity for his neighboring Senators... Not since the jingoes made their first imperious onset for war with Spain to secure the freedom of Cuba has the Senate witnessed another savage attack like Mills’ upon Spain., 53

Opposition to the Morgan-Cameron Resolution, led by Republican Senators George Frisbie Hoar of Massachusetts and Eugene Pryor Hale of Maine, accused supporters of the bill of engineering a foreign crisis for political gains. In one particularly heated

\footnotetext{
${ }^{52}$ John L. Offner, An Unwanted War (Chapel Hill, N.C.: University of North Carolina Press, 1992), 13.

53 "Mills Shouts For War: The Excited Texan Calls For Armed Intervention In Cuba," New York Times, 25 March 1896, p. 16.
} 
exchange in March, Senator Hale accused Ohio Republican John Sherman of using false and inflammatory accounts of the Cuban war to build himself up for a presidential bid. ${ }^{54}$ Hale also condemned the Cubans for their unscrupulous methods in warfare and for wantonly destroying American property on the island. Other arguments against a more aggressive stance on Cuba questioned the constitutionality of congressional recognition of belligerency rights and pointed out that the resolution was non-binding and therefore meaningless. ${ }^{55}$

Despite the opposition, the Morgan-Cameron Resolution passed both the House and Senate with bi-partisan support. The Senate vote was 64 to six with 10 abstentions, while the House vote was 247 to 27 with 80 abstentions. ${ }^{56}$ The overwhelming support of this legislation was significant in that it legitimized in the minds of the public, the right of America to intervene in Cuba if necessary. But, considering these resolutions were non-binding, they were more posturing than an effective plan to solve the problem. Both houses of Congress knew it was unlikely President Cleveland would follow the recommendation of these resolutions. Cleveland had already made it known he believed in Spanish sovereignty in Cuba. In an election year, however, supporting anti-Spanish resolutions became an effective means for congressmen to highlight their differences with an unpopular president.

Once the presidential campaign of 1896 got under way, the Cuban war faded into the back pages of the newspapers. The two major candidates, Republican William McKinley and Democrat (and Populist) William Jennings Bryan, came out in support of

\footnotetext{
${ }^{54}$ Brother of Civil War General William Tecumseh Sherman, John Sherman actually sought the Republican nominee for President three times.

${ }^{55}$ U.S., Congress, Senate, Congressional Record, 54th Cong., 1st sess., 1896, 28, pt. 4: 2587-2594.

${ }^{56}$ U.S., Congress, Senate, Congressional Record, 54th Cong., 1st sess., 1896, 28, pt. 4: 3627-3628.
} 
the Cubans, so there was little mention of the topic on the campaign trail. ${ }^{57}$ However, the Republican, Democrat and Populist platforms all included planks expressing sympathy with the Cubans and called for their independence. The Republican platform plank concerning Cuba, which would become the topic of much debate in the year to come, called for an end to Spanish oppression and concluded with; “...we believe that the Government of the United States should actively use its influence and good offices to restore peace and give independence to the island." ${ }^{\text {58 }}$ Constructed with ambiguous language, the Republican plank on Cuba was designed to be sympathetic yet noncommittal. Democrats would later interpret the wording differently and accuse the Republicans of abandoning their pledge to "liberate" the Cubans.

Although all political parties played lip service to the cause of the Cuban rebels, the prominent issue in the 1896 presidential campaign was whether the monetary standard in America would be based on gold or a combination of gold and silver (bimetallism). McKinley’s campaign lobbied big business and major banks to finance his campaign.$^{59}$ Using the threat of bimetallism to frighten Eastern businessmen who championed the gold standard, McKinley collected a record three and a half million dollars for his campaign.$^{60}$ Bryan, who was nominated by both the Democratic and Populist parties, attracted widespread support among Southern and Western voters and helped unite the fractured Democratic base. In the end though, big money led to a McKinley victory. In spite of the Republicans taking the top spot, Democrats did

\footnotetext{
${ }^{57}$ John L Offner, An Unwanted War (Chapel Hill, N.C.: University of North Carolina Press, 1992) 31.

${ }^{58}$ U.S., Congress, House, Congressman Greene speaking for the Resolution of Civil Service Reform, H. Res. 11508, 55th Cong., 2nd sess., 5 January 1898, Congressional Record, 28: 368.

59،The McKinley Campaign,” New York Times, 14 March 1896, p. 4.

${ }^{60}$ James M. McPherson, To the Best of My Ability (London, U.K.: DK Publishing Inc, 2004), 176.
} 
manage substantial gains in both the House and Senate but fell short of the majority in both. The Democratic strategy of distancing themselves from Cleveland was only a partial success.

With the election over, newspapers once again began devoting substantial space to the Cuban insurgency. In the days preceding McKinley’s inauguration, a new round of debates over the situation in Cuban was suddenly sparked by an event on the island. Pro-independence Cuban General, Antonio Maceo, who had been portrayed in congressional speeches as a courageous “George Washington” figure, was killed in a battle on December 7, 1896. Through newspaper editorials, Maceo had become a romantic figure to Americans who followed his heroic defiance against his Spanish adversaries. When word of Maceo's death reached America it was erroneously reported that the Spaniards had treacherously murdered him during truce negotiations. ${ }^{61}$ This fictitious report was probably manufactured by the Cuban Junta (See pages 22-23) but was cited as fact by members of Congress. Consequently, demonstrations demanding the liberation of Cuba were held in Boston, New York, Pittsburgh, Milwaukee, Chicago, Memphis, St. Louis and numerous other small towns across America. ${ }^{62}$ Congressmen were also flooded with pro-Cuban petitions containing thousands of signatures from their constituents. This public indignation that Congress had carefully nurtured for political benefit was now becoming unmanageable.

On the day of General Maceo’s death, President Cleveland sent a message to Congress that cautioned Congress against taking the United States down a dangerous

\footnotetext{
61 “Maceo Was Assassinated,” New York Times, 13 December 1896, p. 1.

62“Discussing Maceo’s Death” New York Times, 14 December 1896, p.1; Ernest R. May, Imperial Democracy: The Emergence of America as a Great Power (Chicago, Il.: Imprint Publications, 1991), 80-81.
} 
path toward war. He also warned Congress against taking any action to recognize the belligerency of the Cuban insurgents. He argued that according to the principles of international law the circumstances that justify a neutral nation recognizing insurgent belligerency had not been met in Cuba. Cleveland explained that before a revolting community can be recognized they need to establish a functioning government. The Cuban insurgents had failed in this regard, as Cleveland pointed out; “... at the demand of the commander-in-chief of the insurgent army, the putative Cuban government has now given up all attempt to exercise its functions, leaving that government confessedly (what there is the best reason for supposing it always to have been in fact), a government merely on paper”,63

Ignoring Cleveland’s message, on December 21, 1896, Senator Cameron resubmitted his resolution calling for Cuban independence. This time it was submitted as a joint resolution (binding) and required action from Cleveland. ${ }^{64}$ The lawmakers' plan was to pass the resolution overwhelmingly, send it to Cleveland, allow him to veto it, and then override it into law. However, Secretary of State Richard Olney (directed by Cleveland) held a press conference to address the resolution. Olney announced that even if Congress passed the resolution over Cleveland's veto it would not be acted upon. He argued that the power to recognize a state rested exclusively with the executive branch of government and furthermore if any resolution on the subject were passed it would be “important only as advice of great weight, voluntarily tendered to the

\footnotetext{
${ }^{63}$ Grover Cleveland., U.S., Department of State, Foreign Relations of The United States, Government Documents Series, no. 915 (1896), part 1, pp. 26-30.

${ }^{64}$ U.S., Congress, Senate, Congressional Record, 54th Cong., 2nd sess., 1896, 29, pt. 1: 332.
} 
Executive, regarding the manner in which he shall exercise his Constitutional

functions. ${ }^{, 65}$

Jingo congressmen were livid with Olney's announcement and talk of impeachment was heard in the following debates. New Hampshire Republican Senator William E. Chandler fumed over Cleveland's defiance of Congress; "It is worse than that of Andrew Johnson. The only trouble is that if we were to pass it over the veto, and Mr. Cleveland should refuse to execute the law, there would be no time to impeach him. Thank God, however, we will not have him in the Executive Mansion after March the Fourth.” ${ }^{66}$ Following suit, Democratic Senator John T. Morgan accused Cleveland of being a dictator; "If the president has the power to disregard a law enacted by Congress over his veto, we have ceased to live in a land of laws and have found in our presidential office a power that is not pretended to by any monarch that exists in the world. ${ }^{, 67}$ Other Senators chimed in with similar complaints but Cleveland had succeeded in changing the issue to a debate over the constitutional powers of the executive and legislative branches of government. The resolution on Cuba's independence was in effect dead as Congress retired for winter’s recess.

\footnotetext{
65 “Congress Powerless,” New York Times, 20 December 1896, p. 1.

66 “Mr. Chandler is Furious,” New York Times, 20 December 1896, p. 2.

${ }^{67}$ Ibid., p. 2.
} 


\section{Chapter Three}

\section{Cuba: A Political Football}

In the closing weeks of Cleveland's presidency public sentiment continued to be aroused by fresh reports of American citizens being murdered, mistreated and imprisoned in Cuba. William McKinley could only hope to have the problem solved before he took the presidential oath. The incoming president was against sending American men into armed conflict with Spain on humanitarian as well as economic grounds. McKinley had served as a Union volunteer in the Civil War and had been decorated for bravery under fire at the Battle of Antietam. This Civil War confrontation, which would be the bloodiest single-day battle in the history of the United States, left a deep impression on the young soldier. ${ }^{1}$

Apart from these reservations, McKinley was also strongly aligned with the business community which believed a war would have a negative impact on the nation's economy. McKinley had been the darling of the business community since his days as an Ohioan congressman in the House of Representatives. In this position, the future president had authored the pro-business “McKinley Tariff” of 1890 which protected domestic industries by increasing the tariff on foreign products. ${ }^{2}$ Business leaders returned the favor in 1891 by backing McKinley in his successful campaign for governor of Ohio. One of his supporters, Ohio millionaire-businessman Marcus Hanna,

\footnotetext{
${ }^{1}$ James M. McPherson, To the Best of My Ability (London, U.K.: DK Publishing Inc, 2004), 396.

${ }^{2}$ Margaret Leech, In the Days of McKinley (New York, N.Y.: Harper \& Brothers, 1959),44-47.
} 
would become McKinley’s most trusted friend and political advisor. ${ }^{3}$ In 1893 when McKinley went bankrupt and creditors seized his property, it was Hanna along with other businessmen such as Andrew Carnegie and Henry C. Frick who bailed the governor out of debt. ${ }^{4}$

In the 1896 presidential race the business community once again rallied in support of McKinley. Among others, America’s economic triumvirate of the Gilded Age; J.P Morgan, John D. Rockefeller and Andrew Carnegie rewarded the Republican candidate with handsome donations. ${ }^{5}$ These three powerful tycoons, as well as most of the business community openly expressed to McKinley their aversion to war with Spain. ${ }^{6}$ Industrialists believed a foreign war would severely disrupt business as usual. Businessmen preferred the growing domestic market over foreign outlets; but when they did trade overseas, the lions’ share (92.5 percent) went to Europe or European Dominions. ${ }^{7}$ A war with a European power (even though Spain accounted for only a small part of U.S. trade with Europe) could prove disastrous for this trade. ${ }^{8}$ McKinley would have to confront the Cuban crisis from the very beginning of his presidency. The trouble in Cuba had already taken a heavy toll on American

\footnotetext{
${ }^{3}$ Michael E. McGerr, The Decline of Popular Politics. (New York, N.Y.: Oxford University Press, 1986), 140-141.

${ }^{4}$ Margaret Leech, In the Days of McKinley (New York, N.Y.: Harper \& Brothers, 1959), 59.

${ }^{5}$ Stanley Jackson, J.P. Morgan: A Biography. (Briarcliff Manor, N.Y.: Stein and Day Publishers, 1983), 187., Albert Z. Carr. John D. Rockefeller's Secret Weapon. (New York, N.Y.: McGrawHill Book Company Inc.), 110.

6 “Andrew Carnegie's Belief,” New York Times, 28 November 1896, p. 9., "Praise of Message," New York Times, 8 December 1896, p. 3., Jean Strouse, Morgan: American Financier. (New York, N.Y., Random House, 1999), 370-371.

${ }^{7}$ U.S. Department of Treasury. Bureau of Statistics. Merchandise Imports and Exports. Washington: Government Printing Office, 1894., Out of the total \$892,140,572 worth of merchandise produced in the U.S. in 1894, $\$ 869,204,937$ went to the domestic market. Out of the $\$ 22,935,635$ that went to the foreign market, \$21,237,531 went to Europe or European dominions, including Canada and Australia., also see Robert L. Beisner, From the Old Diplomacy to the New: 1865-1900 (Arlington Heights, Il..: Harlan Davidson, Inc., 1986), 22.

${ }^{8}$ Total trade with Spain and Spanish colonies in 1894 amounted to only \$293,900.
} 
businesses and farmers that owned property on the island. The Spanish-American Light Company, which represented a consolidation of five gas and electric companies in Cuba, reported in December of 1896 that the war had halted all revenues from Havana and interest payments to bondholders would have to be suspended. ${ }^{9}$ American sugar and tobacco plantation owners suffered an even worse fate as they helplessly watched Cuban rebels torch thousands of acres of crops as part of their "slash and burn' policy of defeating the Spanish army. Among President McKinley’s backers, John D. Rockefeller had probably lost the most in the Cuban crisis. The oil baron owned a multi-million dollar iron mine near Santiago Cuba but due to the prolonged warfare all production had to be halted. ${ }^{10}$ Against this background, business leaders generally believed that the Spanish government was better equipped to protect American property and ensure a return to the status quo in Cuba. In this regards, McKinley concurred.

In the days before entering the White House, McKinley busied himself with carefully choosing pro-business men to fill his cabinet. Hanna was considered for Secretary of the Treasury but the Ohio businessman made it clear he preferred a seat in the Senate. Bowing to this desire, McKinley appointed Ohio Senator, John Sherman to Secretary of State in order to create a vacancy for Hanna to fill. The Ohio legislature took this cue from McKinley and promptly elected Hanna to fill the remainder of Sherman's term as Ohio Senator. This blatant act of political cronyism caused much consternation among McKinley’s opponents and provided an endless source of mockery of the new administration. Newspapers portrayed Hanna as a puppet master with

\footnotetext{
9“Caused By The Cuban War,” New York Times, 8 December 1896, p. 16.

${ }^{10}$ H.W. Brands., The Reckless Decade: America in the 1890s (Chicago, Il.: University of Chicago Press, 1995), 61.
} 
McKinley dangling at the end of the strings. ${ }^{11}$ Democrats in Congress jokingly called the president "McHanna," and referred to the president's policies as "Hannaism."12 One Senator scornfully asked “If McKinley should die, would Hanna still be President?"13 McKinley, who had a good sense of humor, took this criticism in stride. He had been a Washington insider for almost twenty-five years and knew how the game of politics was played.

After taking office, the newly-elected president made clear his intentions of keeping the United States out of a war with Spain. In his inaugural address, McKinley, like so many presidents before him, reiterated the isolationist theme of Washington' farewell address; "We have cherished the policy of non-intervention with affairs of foreign governments wisely inaugurated by Washington, keeping ourselves free from entanglements, either as allies or foes, content to leave undisturbed with them the settlement of their own domestic concerns...War should never be engaged upon until every agency of peace has failed...” ${ }^{14}$

To implement this policy, McKinley surrounded himself with like-minded congressional leaders; most of whom were wealthy businessmen. In addition to Hanna, other influential members of this “Millionaire’s Club,” would be Senator Nelson Aldrich of Rhode Island and Senator Stephen B. Elkins of West Virginia. McKinley’s vice president, Garret Hobart of New Jersey was also a prominent industrialist and had been hand-picked by Hanna to serve the pro-business

\footnotetext{
${ }^{11}$ Henry B.F. Macfarland, "Mr. McKinley as President,” The Atlantic Monthly, March 1901, Vol. 87. Iss. 521., pp. 299-300. Many historians believe that L. Frank Baum’s Wizard of Oz was modeled after McKinley. The man behind the curtain was Marcus Hannah.

${ }^{12}$ U.S., Congress, House, Congressman Vandiver speaking on the Resolution to Improve Civil Service, H. Res. 4594, 55th Cong., 2d sess., 10 January 1898, Congressional Record, 31: 447.

13 “A Little Story About the Speaker," New York Times, 1 April 1898, p. 3.

14 James M. McPherson, To the Best of My Ability (London, U.K.: DK Publishing Inc, 2004), 396.
} 
administration. ${ }^{15}$ In the House of Representatives, Speaker Thomas B. Reed (ridiculed by Democrats as “Czar Reed”) would become McKinley’s most loyal supporter. These Republican leaders exerted pressure on the rest of their party to abandon all talk of war with Spain. This new agenda was adopted by the Republican ranks and afterwards there was a dramatic change in the congressional proceedings. Republican congressmen, who once delivered long eloquent speeches on the necessity of intervening in Cuba became conspicuously silent. Even the most vocal expansionists in congress such as Henry Cabot Lodge and William P. Frye softened their rhetoric and became more willing to pursue peace. ${ }^{16}$ The Republican leadership in both houses of Congress also blocked resolutions or debates concerning the Cuban issue. This Republican about-face would become a major source of partisan bickering in the months ahead.

Congressional Democrats and Populists were opposed to the McKinley Administration's pursuit of peace with Spain from the beginning. These leaders were not about to surrender the Cuban issue that had been so carefully nurtured for their own political purposes. If Republicans insisted on non-intervention, they would be held to account politically for betraying the Cubans for their own selfish reasons. Throughout the long debate preceding the Spanish-American War the public was constantly reminded of how the Republicans reversed their policy of supporting the Cuban rebellion. "Before the election the Republican Party is Dr. Jekyll, and after the election

\footnotetext{
${ }^{15}$ Margaret Leech, In the Days of McKinley (New York, N.Y.: Harper \& Brothers, 1959), 83.

16 “Cuban Sentiment Moderating,” New York Times, 9 December 1896, p.1.
} 
Mr. Hyde,” Nebraska Populist William L. Greene joked to members of the House. ${ }^{17}$

Arkansas Democratic Congressman Hugh Dinsmore similarly mocked the Republicans

for changing their position:

Where now is the clarion voice of my distinguished colleague on the committee, the gentleman from Michigan (Mr. Wm. Alden Smith), whose fervid, eloquent appeals stirred the souls of us all? What has become of my other colleague, the gentleman from Pennsylvania (Mr. Adams), who fairly fattened the Record with reasons, in the last Congress, why we should recognize the belligerent rights of Cuba... Will he tell us now that his argument was sophistry, his position unsound? ${ }^{18}$

The nation's newspapers also noted the change in sentiment among the Republican members of the Foreign Affairs Committee who were now backing away from provoking Spain and blocking any forwarded resolutions to give the Cuban insurgents belligerency status. In December of 1896, the New York Times reported; "Members of that committee who at the last session were radical in their opposition to Spain and bubbling over with enthusiasm for the Cuban patriots have changed front since their return to Washington and are now among the most conservative men on the committee."19

Several Republicans defended their change in position by claiming that the incoming McKinley Administration should not be confronted by such a serious international dilemma upon entering the White House. They believed it important for McKinley to evaluate the situation and formulate his own Cuban policy. Other

\footnotetext{
${ }^{17}$ U.S., Congress, House, Congressman Greene speaking on Senate Resolution of Recognition of Public War in Cuba, S. Res. 26, 55th Cong., 2d sess., 5 January 1898, Congressional Record, , 31:368.

${ }^{18}$ U.S., Congress, House, Congressman Dinsmore speaking for the Consular and Diplomatic Appropriation Bill, H. Res. 4594, 55th Cong., 2d sess., 19 January 1898, Congressional Record, 31:770.

19 “Change of Sentiment,” New York Times, 19 December 1896, p. 1.
} 
Republicans declared that the time for the United States to intervene in Cuba had passed. Arguing that American commerce on the island had all but been destroyed, a member of the Foreign Affairs Committee assessed the situation, "If we had intervened a year ago... American property rights in the island would have suffered only a partial interference. Today, as I say, the island is bankrupt, and its trade will be worth nothing to the United States for twenty years."20

Throughout the rest of 1897 and into 1898 the Democrats and Populists became ever more hawkish on the prospect of war with Spain. Their strategy was to paint the worst possible portrait of the atrocities in Cuba and then blame the unsympathetic Republicans for conspiring with the Spaniards and ignoring the will of the American people. Republicans were accused of being hired traitors, cowards, unpatriotic and mindless slaves to their master McKinley. One Democratic Congressman even ridiculed Republicans for worshiping Benedict Arnold as their patron saint. ${ }^{21}$ With acerbic hyperbole, Democrats blamed the Republicans for enabling the Spaniards to continue the extermination of the Cubans unhindered. In some of the most vitriolic rhetoric, the Spanish military's actions in Cuba were declared to be "more fiendish and devilish than have blackened the pages of history since the days of Caligula."22 Another Congressman declared that Cuba was worse than Dante’s “inner recess of hell." ${ }^{23}$ These colorful tirades were designed to antagonize the Republicans as well as provide titillating episodes for the newspapers to cover.

\footnotetext{
20 “Republicans Object to a War,” New York Times, 19 December 1896, p. 1.

${ }^{21}$ U.S., Congress, House, Congressman Sulloway speaking on the Resolution to Improve Civil Service, H. Res. 4594, 55th Cong., 2d sess., 10 January 1898, Congressional Record, 31: 499.

${ }^{22}$ U.S., Congress, House, Congressman Castle speaking for the Consular and Diplomatic Appropriation Bill, H. Res. 4594, 55th Cong., 2d sess., 19 January 1898, Congressional Record, 31:764.

${ }^{23}$ U.S., Congress, Senate, Senator Mason speaking for the Resolution of Recognition of Public War in Cuba, S. Res. 26, 55th Cong., 2d sess., 19 January 1898, Congressional Record, 31:1581.
} 
Democrats also criticized Republicans for being in the pocket of big business or financiers. Democrats such as Congressman Cyrus A. Sulloway made outrageous claims that the big European money interests controlled the Republican Party. Sulloway contended that the House of Rothschild owned two-hundred million dollars in Cuban bonds and should Cuba achieve her independence these bonds would depreciate in value, hence; "Rothschild controls (J.P.) Morgan, Morgan controls Hanna and Hanna controls McKinley, the Supreme Court, the Senate, and the House of Representatives. Hanna is America and America is Hanna." ${ }^{24}$ Democratic Congressman Hugh A. Dinsmore likewise blamed Republicans' allegiance to big business as the reason for their unwillingness to intervene in Cuba; "True to your political obligations, you are unanimous in your support of trusts, syndicates, and organized capital. You are still true in your devotion to protecting the organized manufactures of this country.",25

Congressman Jerry Simpson, a Populist from Kansas, argued that both Republicans and Democrats were controlled by business interests. Simpson claimed that Cleveland had prevented a war with Spain because he and his administration were the agents, "of the bond-holding interests of the country and the 400,000,000 of bonds that Spain has issued to carry on the Cuban war ... the Republican Party will follow in the same line of action.,26

\footnotetext{
${ }^{24}$ U.S., Congress, House, Congressman Sulloway speaking on the Resolution to Improve Civil Service, H. Res. 4594, 55th Cong., 2d sess., 10 January 1898, Congressional Record, 31: 499. ${ }^{25}$ U.S., Congress, House, Congressman Dinsmore speaking for the Consular and Diplomatic Appropriation Bill, H. Res. 4594, 55th Cong., 2d sess., 19 January 1898, Congressional Record, 31:771.

${ }^{26}$ U.S., Congress, House, Congressman Simpson speaking on Senate Resolution of Recognition of Public War in Cuba, S. Res. 26, 55th Cong., 2d sess., 20 January 1898, Congressional Record, , 31: 803.; This issuing of Spanish bonds was mentioned by several congressmen with differing accounts on their value and who owned them. I have not been able to validate any of these claims from another source.
} 
In response to such attacks on Republicans, business leaders criticized the Democrats and Populists in Congress for playing politics with the Cuban crisis. Writing in the New York Times, businessman Abraham Miller accused Democrats and Populists of trying to embroil the United States in a foreign war to unite the people around an external issue. He specifically targeted the Populists for pushing for war because “A foreign war would more surely than anything else enable them to compass their ends... and quickly send us to a silver basis.”27

Convinced that exploiting the Cuban crisis was becoming a winning strategy, Democrats such as New York Congressman William Sulzer compared the Cuban insurgents’ struggle against Spain with the United States’ own war for independence. To loud applause from the Democrats present in the House, he proclaimed that his party was on the right side of history; “The Democrats in this House are in favor of passing a joint resolution granting belligerent rights to the Cubans. The Republicans have persistently refused to permit a vote on the question. The people of this country will hold the Republican party responsible for that action at the coming election.”28

Republican Representative Robert Adams took the floor to question the patriotism of the Democrats who were aggravating a foreign crisis to win seats in the House; "I look hopefully forward to the day when our foreign policy will be national and permanent in its character and not subject to party strife."29

\footnotetext{
27 “The Obstructionist Senate,” The New York Times., 22 February 1897, p.6.

${ }^{28}$ U.S., Congress, House, Congressman Sulzer speaking for the Consular and Diplomatic Appropriation Bill, H. Res. 4594, 55th Cong., 2d sess., 19 January 1898, Congressional Record, 31: 763.

${ }^{29}$ U.S., Congress, House, Congressman Adams speaking for the Consular and Diplomatic Appropriation Bill, H. Res. 4594, 55th Cong., 2d sess., 19 January 1898, Congressional Record, 31: 773.
} 
Several Republicans conceded that ignoring the Cuban situation posed a grave political danger in upcoming elections. Kentucky Republican Representative David G. Colson cautioned his colleagues; "I say if we do not terminate this unholy warfare [in Cuba] I expect to see the next House of Representatives have in it many faces that we do not see here today... ${ }^{30}$ Colson’s fellow Kentuckian, Democratic Congressman Albert S. Berry agreed that Republicans would be punished by the electorate if they failed to liberate Cuba and openly bragged, "I think the Republicans are on the run... the handwriting on the wall indicates that in the very next election they will find themselves in the minority in this country."31 Democrats present in Congress laughed and applauded Berry’s braggadocio. In response to this taunting, Republican Congressman Henry U. Johnson of Indiana warned the Democrats they were playing a dangerous game with America's foreign policy; “I wish it were possible that gentlemen could take a broader view of this subject [the Cuban civil war] than merely to consider it as something upon which they may hope to obtain a partisan advantage. ${ }^{32}$ Later in the debate, Johnson bolstered his criticism of Democratic demagoguery by reading an article from the Washington Post that described the Democrats as “.... a thoughtless and hot-headed minority ... that was creating a movement for war that was ... clothed in the alluring garb of altruism and paraded as a noble effort of benevolence. But its moaning is war.

\footnotetext{
${ }^{30}$ U.S., Congress, House, Congressman Colson speaking for the Consular and Diplomatic Appropriation Bill, H. Res. 4594, 55th Cong., 2d sess., 18 January 1898, Congressional Record, 31: 738.

${ }^{31}$ U.S., Congress, House, Congressman Berry speaking for the Consular and Diplomatic Appropriation Bill, H. Res. 4594, 55th Cong., 2d sess., 19 January 1898, Congressional Record, 31: 775.

${ }^{32}$ U.S., Congress, House, Congressman Johnson speaking during the debate on Consular and Diplomatic Appropriation Bill, H. Res. 4594, 55th Cong., 2d sess., 19 January 1898, Congressional Record, 31: 799.
} 
Its only possible result is carnage, barbarism, disaster...[the] war cry is inspired more by partisan ardor than by intelligent conviction." ${ }^{33}$

This scathing article in the Washington Post had stated the obvious about Democrats' effort to wrap themselves in the American flag. It is important to consider that these legislators, who were mainly from the South, demanded freedom for the AfroCubans, while they denied their own black neighbors basic civil and human rights. For example, Alabama Democratic Senator John T. Morgan, a former Brigadier General in the Confederate Army and self-proclaimed white separatist, led the Senate in its crusade to liberate Cuba. While serving as Chairman of the Senate Foreign Relations Committee, Morgan had cried crocodile tears for the oppressed Cubans and submitted several resolutions granting belligerent rights to the insurgents. But concerning civil rights in the United States, Morgan supported repealing the Fifteenth Amendment to the U.S. Constitution that prevented voting rights based on race. ${ }^{34}$

Similarly, South Carolina Democratic Senator, (“Pitchfork”) Benjamin Tillman, who supported American intervention on behalf of the Cuban insurgency, was largely responsible for his own state's Jim Crow laws. ${ }^{35}$ As Tillman proudly proclaimed in 1900; "We have done our level best [to prevent blacks from voting]... we have scratched

\footnotetext{
${ }^{33}$ Ibid

34 "Senator John Tyler Morgan and Negro Colonization in the Philippines, 1901 to 1902" Joseph O. Baylen and John Hammond Moore. Phylon Journal, Vol. 29, No. 1. $1^{\text {st }}$ Qtr., 1968., pp.65-75

${ }^{35}$ U.S., Congress, Senator Tillman speaking for the Resolution to Grant Belligerency Rights to the Cuban Insurgency S. Res. $55^{\text {th }}$ Cong., 2 sess., 5 March 1898, Congressional Record, 6530., Francis Butler Simkins, Pitchfork Ben Tillman: South Carolinian (Baton Rouge: Louisiana University Press, 1944), 292-299.
} 
our heads to find out how we could eliminate the last one of them. We stuffed ballot boxes. We shot them... We are not ashamed of it." ${ }^{36}$

Missouri Democratic Congressman David de Armond is another glaring example of this hypocrisy. In his own pursuit of the job as Speaker of the House, De Armond was one of the most outspoken supporters of a war with Spain. He was a demagogue who bitterly attacked the Republicans for betraying the suffering Cuban people (See page 52). His long tirades in Congress were filled with platitudes for the "noble” and “courageous” Cuban people. But on the day Congress passed the war resolution against Spain, he argued against giving rights to blacks in America on the basis they were “almost too ignorant to eat, scarcely wise enough to breathe, mere existing human machines.”37

Republican Congressman Charles Boutelle of Maine, assailed these incongruent positions by pointing out that millions of black Americans were denied their "sacred rights” while Democrats insist we “...dash across the Gulf of Mexico and establish and maintain the independence and freedom of the insurgents in the island of Cuba." 38 The black community was equally skeptical of Congressional sympathy for Cuban rebels. Shortly after the war, a group of black citizens from Massachusetts wrote an open letter to McKinley expressing their indignation over the inconsistencies in American policy. This stinging indictment of both the Congress and McKinley questioned why the United

\footnotetext{
${ }^{36}$ U.S., Congress, Senate, Senator Tillman speaking against the Resolution Against State Discrimination Against Negro Suffrage, S. Res. 174, 56th Cong., 1st sess., 26 February 1900, Congressional Record, 332242 -2245.

${ }^{37}$ Rayford W. Logan, The Betrayal of the Negro, from Rutherford B. Hayes to Woodrow Wilson (New York N.Y.: Da Capo Press, 1965), 99.

${ }^{38}$ U.S., Congress, House, Congressman Boutelle speaking against the Resolution to Recognize the

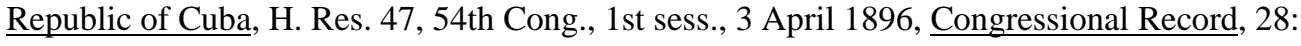
3550 .
} 
States would go to war over humanitarian reasons in Cuba while maintaining a

"shameful silence," on the violent conditions in the South. ${ }^{39}$

${ }^{39}$ The Annals of America: Primary Sources of American History 1895-1904., (Encyclopedia Britannica, Inc., 1976.), 321- 326. 


\section{$\underline{\text { Chapter Four }}$}

\section{Run up to War}

Even though the Democrats kept up a steady attack on Republicans and McKinley, the President continued to work diligently for a peaceful settlement. First, he sent former New York Republican Congressman Stewart L. Woodford to Madrid to serve as his minister. Once in the Spanish capital, Woodford would become McKinley's intermediary with the government and the Queen Regent María Cristina. ${ }^{1}$ McKinley’s instructions, as set forth in a letter from Secretary of State Sherman, were for Woodford to establish friendly contacts with the Spanish authorities and negotiate a peaceful settlement to the conflict whereby Cuba would be granted autonomy based on the Canadian model. If the Spanish agreed, McKinley promised to likewise negotiate with the Cuban insurgents to accept these terms. ${ }^{2}$ McKinley realized that Woodford's mission would be difficult considering the unyielding position the Conservative Spanish Prime Minister Antonio Cánovas del Castillo had taken on the Cuban insurgency from the beginning.

But, as fate would have it, while en route to his new post, word reached Woodford that Prime Minister Cánovas del Castillo had been assassinated. ${ }^{3}$ Shortly afterwards, the Conservative government in Madrid collapsed and the Queen Regent

\footnotetext{
${ }^{1}$ María Cristina of Austria served as Queen Regent after her husband King Alfonso XII died and until their son Alfonso XIII was old enough to take the throne in 1902.

${ }^{2}$ U.S., Department of State, Foreign Relations of The United States, Government Document Series, no. 4 and 24 (1897) pp. 558-565.

${ }^{3}$ Cánovas was shot dead by an Italian anarchist , Michele Angiolillo, at a spa in the town of Mondragon. McKinley would also be assassinated by a self-proclaimed anarchist, Leon Czolgosz.
} 
appointed a new Liberal Cabinet with Práxedes Mateo Sagasta as Prime Minister. ${ }^{4}$

Making Woodford's task easier, this new government was reform-minded and willing to grant Cuba a system of autonomy much like McKinley had suggested. Beyond this, the new leaders also ordered General Weyler removed from his position in Cuba and replaced by a less repressive leader; General Ramon Blanco y Erenas. After his arrival on the island, General Blanco instituted more humane policies toward the Cubans and quickly began to reverse Weyler's severe reconcentration policy. ${ }^{5}$

Through further negotiation Woodford was also able to secure the release of all American prisoners still held on the island. In a sign of goodwill, Spain even initiated talks on a new reciprocal trade agreement with the United States and Cuba. Taking advantage of the new-found cooperation among the two nations, McKinley requested that Spain allow the United States to ship food and medicine to the starving Cuban citizens. After some heated debate among Spanish leaders, McKinley’s plan was finally accepted and the Spanish officials even helped distribute the supplies. ${ }^{6}$ By the end of 1897, Spanish-American relations were, on all accounts, improving remarkably. Through McKinley’s skills as a politician and the luck of an assassin’s bullet, war at last seemed avoidable.

On December 6, 1897, McKinley submitted to Congress a report on the diplomatic progress being made between Spain and the United States. ${ }^{7} \quad$ Loyal Republicans in congress such as Pennsylvania Congressman Robert Adams touted these successes; "Within sixty days of the time that the Republican President took his seat, the

\footnotetext{
4 “New Spanish Ministry,” New York Times, 3 October 1897, p. 1.

5 “Help For The Reconcentrados,” New York Times, 13 November 1897, p. 3.

${ }^{6}$ John L Offner, An Unwanted War (Chapel Hill, N.C.: University of North Carolina Press, 1992), 81-82.

${ }^{7}$ U.S., Congress, House, Congressional Record, 55th Cong., 2nd sess., 1897, 31, pt.1: 5.
} 
doors of the dungeon of Cuba were flung open...Spain has responded to these friendly demands of this government in every particular. Weyler was recalled...the reconcentrados have been gradually returned to their homes." ${ }^{8}$

Republicans also argued that since Spain was in the process of complying with all of McKinley's demands it would be imprudent for America to take a more belligerent stance toward Cuba. Democrats, on the other hand, complained that McKinley could not take any credit for the positive changes occurring in Cuba. They insisted that the only reasons for a glimmer of hope on the island were the result of the assassination of Prime Minister Cánovas del Castillo and Spain was growing worried that the Untied States would soon take action in Cuba. Congressman Dinsmore bragged that it was actually the Democratic Party's leadership on the Cuban issue that had forced Spain to the negotiating table; "They saw that every organized body in the United States almost had expressed its sympathy for the Cuban patriots and demanded intervention on the part of this Government." ${ }^{\prime 9}$ The Democrats also argued that the Cubans themselves had not been a party in the negotiations with Spain and would not fully accept the conditions. Moreover, they derided McKinley for betraying the Cubans for a lucrative trade deal with the Spaniards. In reality, the Democrats were correct that the reforms would have limited success. The Cuban rebels publicly announced their rejection of "autonomy" and vowed to continue the struggle for nothing short of total independence. ${ }^{10}$

\footnotetext{
${ }^{8}$ U.S., Congress, House, Congressional Record, 55th Cong., 2nd sess., 1897, 31, pt 1: 773.

${ }^{9}$ U.S., Congress, House, Congressman Dinsmore speaking for the Consular and Diplomatic Appropriation Bill, H. Res. 4594, 55th Cong., 2d sess., 19 January 1898, Congressional Record, $31: 770$

10 “Autonomy In Cuba,” New York Times, 24 December 1897, p. 6.
} 
This issue of reforms in Cuba was equally as divisive among the two major Spanish political factions. Conservative members of the military in Havana were upset by General Weyler's recall and began staging riots. After several days of demonstrations, they attacked and burned down a pro-Sagasta newspaper office. Fearing that this escalation in violence threatened American citizens living in Havana, McKinley accepted Cuba’s Council General Fitzhugh Lee’s recommendation and sent the battleship USS Maine to Havana harbor. ${ }^{11}$ McKinley hoped that this show of force would calm the situation in Havana and would also placate congressmen who were demanding some action on the President's part. This action, however, backfired when Democrats decided to use this as another opportunity to ridicule the President. Congressman de Armond sarcastically asked Congress; "Is she [the USS Maine] there to vindicate our manhood, to protect American citizens, to proclaim what is in the hearts of the brave people of this country- sympathy for the struggling Cubans and detestation and horror over the outrages perpetrated upon them? Oh, no!... her visit is merely a resumption of friendly relations... in token of American humility and Spanish condescension!"12

Other Democrats expressed the belief that McKinley had a more nefarious reason to send the USS Maine to Havana. In a long harangue against McKinley, Democratic Congressman Robert W. Miers of Indiana claimed the battleship’s real mission in Cuba was to prop up the weak Spanish government by assisting the Spanish military in oppressing the rebels. Miers concluded his speech by accusing the

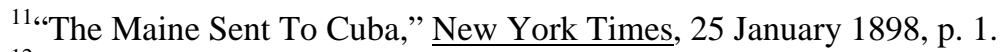

${ }^{12}$ U.S., Congress, House, Congressman de Armond speaking on the Indian Department Appropriation Bill, H. Res. 6896, 55th Cong., 2d sess., 27 January 1898, Congressional Record, 31: 1113.
} 
Republicans of conspiring with America's sworn enemy: "The Stars and Stripes are waving above the walls of Morro Castle [in Havana] not as a promise of liberty for Cuba, but as a refuge for Blanco and the other officers of the Spanish Court...Is this the way the Republican party keeps its promises? While Nero fiddles Rome burns.”13

Despite the Democrats' accusations of collusion with the enemy and the vitriolic call for intervention in Cuba, McKinley was still optimistic about finding a peaceful settlement. The President had good reason to believe his efforts for peace were finding a receptive audience in the American public. George M. Cortelyou, McKinley’s secretary, reported that in the months leading up to the war; "90 percent of the mail coming to the White House had supported the President’s pacific course."14

The majority of citizens who wrote McKinley did express their confidence in his wise leadership in such a troublesome time. Civil War veterans complimented the president in resisting the martial spirit that aroused those younger Americans who had never experienced the horrors of war. Business leaders openly worried about the impact a war would have on the flow of commerce. Ohio Banker and Former Speaker of the House Joseph Warren Keifer cautioned McKinley; “The expense of such a war would be beyond calculation...All business interests would be suddenly deranged." ${ }^{15}$

Religious leaders and peace organizations also praised McKinley for his determination in avoiding a conflict. The Universal Peace Union of Philadelphia extended their best wishes to McKinley and invited him to speak in an upcoming

\footnotetext{
${ }^{13}$ U.S., Congress, House, Congressman Miers speaking on the Indian Department Appropriation Bill, H. Res. 6896, 55th Cong., 2d sess., 29 January 1898, Congressional Record, 31: 1210.

${ }^{14}$ Richard F. Hamilton, President McKinley, War and Empire (New Brunswick, N.J.: Transaction Publishers, 2006), 110.

${ }^{15}$ J. Warren Keifer to McKinley, February 25, 1898, McKinley Papers, Reel 60.
} 
meeting. ${ }^{16}$ Other letters to the White House spoke of the political motivations of those behind the war movement. A "Mr. Dodger" warned McKinley that his political enemies would use the situation in Cuba against him regardless of what action the president took; "Those very people, who, for no just cause, would push our country into the unknown, would, as soon as they felt the distress that war brings and see its cruelty, be the first to denounce the Administration and everyone connected with the bringing on of the war."17 The letters that opposed McKinley's pacific stance usually argued for war on the basis of humanitarian concerns and the nations' honor. Although these letters were respectful for the most part, several warned McKinley of disregarding those who desired intervention in Cuba in favor of the business community. Charles Henderson of New York City expressed his thoughts to the president; "I trust, as a humble citizen, that your cabinet will turn a deaf ear to the representatives of the great banking syndicates and corporations who are reported to be offering suggestions in regards to a settlement of the Cuban question... the people of our great country will not allow it for a moment."18 Sitting aside the Cuban question, McKinley spent the first month of 1898 attending to other matters of state. In January the president and Mrs. McKinley filled their schedule with receptions and dinner parties; hosting a record number of guests. ${ }^{19}$ Late in the month, McKinley traveled to New York City to address the National Association of Manufacturers at their third -annual convention. ${ }^{20}$ McKinley made no mention of the Cuban situation during his long oration but did

\footnotetext{
${ }^{16}$ The Universal Peace Union to McKinley, March 15, 1898, McKinley Papers, Reel 61.

${ }^{17}$ Mr. Dodger to McKinley, February21, 1898, McKinley Papers, Reel 60.

${ }^{18}$ Charles Henderson to McKinley, 16 March 1898, McKinley Papers, Reel 60.

${ }^{19}$ Margaret Leech, In the Days of McKinley (New York, N.Y.: Harper \& Brothers, 1959),445.

${ }^{20}$ As Ohio Governor, McKinley had hosted the organization's first convention.
} 
assure the businessmen he was in "full accord" with their various domestic and international goals. $^{21}$

On February 1, President McKinley hosted a diner for foreign diplomats at the White House. The event was an elaborate affair, attended by representatives of thirty foreign nations and their wives along with other government officials. Adhering to proper protocol, McKinley stood before the guests seated at the long table and toasted international cooperation and peace among the nations of the world. The Spanish Ambassador, Enrique Dupuy de Lôme, sat four chairs down the table on McKinley's right. ${ }^{22}$

If McKinley believed his efforts to avoid a war with Spain had been successful two events in February of 1898 were about to shake his confidence. The first event occurred on February 9, 1898, when a private letter written by Spanish Ambassador Enrique Dupuy de Lôme to the Foreign Minister of Spain in Havana, Don Jose Canelejas, was intercepted. In this letter, de Lôme caustically ridiculed McKinley and Spanish-American relations. Stolen by a member of the Cuban Junta, the letter was quickly translated into English and sent to the major newspapers for its propaganda value. The insulting language in the letter criticized McKinley for being "weak” and a “would-be politician.” Even more damaging, the letter described the proposed Cuban autonomy as simply a means of diverting American attention from Spanish to Cuban officials. $^{23}$ While most newspapers waited to verify the authenticity, Hearst's Journal

\footnotetext{
${ }^{21}$ R. A. C. Smith to McKinley (copy of speech), 27 January 1898, McKinley Papers, Reel 60. 22 Diplomatic Dinner Seating Arraignment 26 January 1898, McKinley Papers, Reel 60.

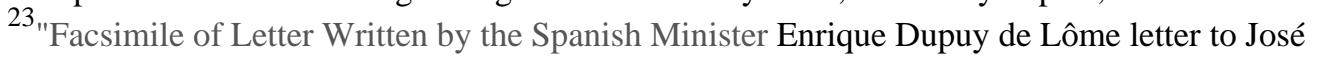
Canalejas” (Record Group 59) [Electronic Records]; Notes from the Spanish Legation in the U. S to the Department of State, 1790-1906, LICON, Textual Archives Service Division (NWCTB), National Archives Building at $7^{\text {th }}$ and Pennsylvania Avenue NW, Washington, DC.
} 
printed it the following day with the headline, “The Worst Insult to the United States in its History."24

As could be expected, McKinley was upset at this affront to his character and called a special Cabinet meeting to discuss his administration’s options in dealing with this crisis. After a lengthy meeting, McKinley sent a message to Spain calling for the recall of de Lôme and an apology. Spain quickly consented to his wishes, but the damage had been done. The New York Times ran de Lôme's letter on the front page the next day and spoke of the outrage felt by many Americans and congressmen who were offended by the slanderous attack on McKinley. ${ }^{25}$ It is important to note that McKinley's opponents in Congress had openly used many of the same or worse criticisms against the President.

Only a week after this scandalous news triggered public indignation, an even more devastating news story splashed across the nation’s headlines. On the night of February 15, the USS Maine blew up in Havana Harbor killing two hundred and sixty six sailors. The headlines in the majority of American newspapers were remarkably restrained in their account of the events. Most did not mention the possibility of Spanish involvement. The Wall Street Journal reported that "the Spanish army and navy officers are rendering every assistance” to the Maine sailors. ${ }^{26}$ Pulitzer's World commended Spanish sailors who "worked like heroes to save the few struggling Maine men now

\footnotetext{
${ }^{24}$ Donald H. Dyal, Historical Dictionary of the Spanish American War (Westport, CT.: Greenwood Publishing Group, Inc., 1996), 115.

25 “Seeking De Lôme’s Recall," New York Times, 10 February 1898, p. 1.

26 “The Maine Explosion,” Wall Street Journal, 16 February 1898, p. 1.
} 
recovering in Ambrosio Hospital. ${ }^{27}$ Other newspapers likewise avoided leveling blame at Spain and instead cited the probability of a coal bunker igniting the fire. ${ }^{28}$

The mood in Congress was initially sober and subdued as well. Bi-partisan resolutions were offered in the Senate calling for an inquiry into the explosion. Debate centered on who was responsible for directing the investigation and what role the Committee on Naval Affairs played in setting the guidelines for the report. A cautious McKinley reported to waiting reporters at the White House that the Maine explosion was “probably an accident.” He then asked Americans for patience while an investigation team would be sent to Havana to search the wreckage for the cause of the explosion. ${ }^{29}$

While the nation held its breath waiting for the results of the inquiry, another event provoked public outcry for intervention in Cuba. On March 17, 1898, Republican Senator Redfield Proctor from Vermont arrived in Washington with a long-awaited report on conditions in Cuba. Proctor, a well-respected former Secretary of War and successful businessman, had announced some weeks earlier that he was going to take an extensive tour of Cuba to ascertain the true conditions of the people. Proctor's factfinding mission was important to the public as well as lawmakers, because of his credibility. The Senator had previously been against any American intervention, so it was anticipated that his findings would be free of any biases that had plagued similar reports. ${ }^{30}$ From the day Proctor landed, newspaper reporters followed his journey around the island. American newspapers ran daily stories on Proctor's visits to the

\footnotetext{
27 “Havana’s Show of Grief,” The World 18 February 1898, p.2.

${ }^{28}$ John L Offner, An Unwanted War (Chapel Hill, N.C.: University of North Carolina Press, 1992),123.

29،"President Getting the News" New York Times, 16 February 1898, p. 1.

${ }^{30}$ U.S., Congress, Senate, Congressional Records, $54^{\text {th }}$ Cong., $1^{\text {st }}$ sess., 1896, 28, pt.4: 3193-3194
} 
homes of Spanish and American officials, refugee camps, military prisons, relief depots and orphanages run by the Red Cross. Even though the media reported on the conditions the Senator encountered, Proctor himself refrained from making any observations until he could address the Senate. ${ }^{31}$

After Proctor returned to Florida, he made his way back to Washington by train refusing any comments to reporters. Upon his arrival on March 17, he proceeded directly to Capitol Hill and interrupted the usual proceedings on the Senate floor. As Proctor approached the podium, every Senator in Congress was present and attentively waiting. In an authoritative and dispassionate manner, Proctor meticulously laid out the hard facts on the horrendous conditions that existed on the island. He admitted that when he left for his visit he did not believe the sensational news reports but was now convinced they were correct or worse. In his description, Proctor spoke of thousands of emaciated women and children dying of starvation and disease. The remaining insurgents on the island, he said, were still stubbornly holding out for independence. More importantly, he proclaimed the war to be a bloody stalemate that only outside intervention could end. ${ }^{32}$ Proctor's account of the desperate situation in Cuba had a profound effect on many who had heretofore resisted American intervention. Many in the business and religious communities, which had consistently opposed war, were finally persuaded by Proctor’s speech. ${ }^{33}$

\footnotetext{
${ }^{31}$ Ernest R. May, Imperial Democracy: The Emergence of America as a Great Power (Chicago, Il.: Imprint Publications, 1991), pp. 144-145., Donald H. Dyal, Historical Dictionary of the Spanish American War (Westport, CT.: Greenwood Publishing Group, Inc., 1996), p.268.

${ }^{32}$ U.S., Congress, House, Congressional Record, 55th Cong., 2nd sess., 1898, 31, pt.3: 2916-2919., “Cuba As Proctor Saw It,” New York Times, 18 March 1898, p. 1.

${ }^{33}$ Donald H. Dyal, Historical Dictionary of the Spanish American War (Westport, CT.: Greenwood Publishing Group, Inc., 1996), p. 268.
} 
Soon after Proctor's speech the old Senator shared a buggy ride to Capitol Hill with fellow West Virginia Republican Senator Stephen B. Elkins. As a former Secretary of War, Elkins was conversant in foreign policy issues. On the way, Elkins praised the respected statesman on his speech and told him that he had "stirred the country as it never has been stirred.” Elkins continued to praise Proctor's speech as a powerful and colorful presentation not unlike that of the commentaries of Julius Caesar and the memoirs of Grant. But honest to his anti-war convictions, Elkins admitted to Proctor that he felt the speech was mischievous and dangerous. Elkins told him that he had “taken a great responsibility and done great harm., 34

A few days later the Navy's report on the Maine explosion arrived. The Navy investigators had decided that it was an external explosion that had caused the destruction. ${ }^{35}$ Coming on the heels of Proctor's report to Congress, the timing could not have been worse. Many Americans immediately suspected the explosion was a deliberate torpedo attack by the Spanish Navy. McKinley, knowing what the ramifications of this report would be, met with members from all political parties and asked them for patience while his administration continued to pursue a diplomatic solution. Most in Congress, including Republicans who had supported McKinley from the start, knew that war was now inevitable. Several Republicans met with McKinley to warn him that their party would suffer a huge defeat in November if he did not act soon. On April 1, the New York Times reported that 200 Republicans had defected from McKinley and were now ready to vote for war. In the same article, House Speaker Thomas Reed responded to a governor's plea to dissuade the Republican defection; "He

\footnotetext{
${ }^{34}$ Elkins’ Journal., West Virginia Collection., A\&M No. 2175. Box 4, p.32.

35 “Court Of Inquiry,” Fairmont Free Press. 31 May 1898., p.1.
} 
might as well ask me to stand out in the middle of a Kansas waste and dissuade a

cyclone.”36 Lacking options, McKinley finally agreed to draft a message that would ask Congress for the authority to use the military and naval forces as might be necessary to secure peace and a stable government in Cuba.

McKinley, however, delayed sending the message to Congress while he made one last-ditch effort to solve the crisis diplomatically. First, through Spanish Minister Stewart Woodford, McKinley urged the Spanish government to declare an armistice in Cuba, promise the people "full self-government, with reasonable indemnity," and accept American arbitration. ${ }^{37}$ Secondly and clandestinely, McKinley sent word to the Vatican, via Saint Paul, Minnesota Archbishop, John Ireland, that he was willing to have Pope Leo XIII mediate an end to the crisis. To avoid public and congressional awareness and condemnation of these negotiations, McKinley drafted Senator Stephen B. Elkins to conduct negotiations with all parties. ${ }^{38}$

Senator Elkins was well suited for this task. In becoming one of the most successful businessmen in the country, Elkins had excelled in the art of compromise and gentle (and not so gentle) arm twisting. He had brought these skills to the Senate where he was known for his political prowess. ${ }^{39}$ In addition, Elkins was personally acquainted with Archbishop Ireland, the Spanish Prime Minister Luis Polo de Barnabé, and members of the Cuban Junta. The Archbishop was equally important in these

\footnotetext{
36 “Congress Is Impatient,” New York Times. 1 April 1898, p. 1.

37 John L Offner, An Unwanted War (Chapel Hill, N.C.: University of North Carolina Press, 1992), 154.

${ }^{38}$ Elkins’ Journal., A\&M No. 2175. Box 4., pp. 1-2.

${ }^{39}$ It was widely acknowledged in Congress and newspapers that Senator Elkins had an inordinate amount of influence over McKinley and other Congressmen. McKinley's letters contain many requests from Elkins to appoint his friends and associates to leadership positions. Most if not all of these requests were granted. Also SEE “Editorial Article 2," New York Times. 3 February 1898., p. 6.
} 
negotiations because not only was he the Pope's surrogate but according to Elkins, a loyal Republican and "had more influence with the Administration than any other church authority in the United States."40

On the morning of April 3, Elkins arranged for a three-way meeting between himself, Archbishop Ireland and Spanish Minister Polo at the Elkins’ residence in Washington. After the usual exchange of courtesies, Elkins and Ireland began to emphatically present the dilemma facing Spain. They warned Polo that Congress alone now had the power to declare war on Spain and was poised to do so. The two men explained that the only avenue left for Spain was to declare an immediate armistice in Cuba. Polo balked at this suggestion and maintained that if his country took this course of action it would be considered a concession to the insurgents and would sacrifice Spain’s dignity. The debate continued back and forth until the three surrogates agreed to propose a temporary armistice lasting six months. The Archbishop left Elkins' house to send a dispatch to the Pope while Polo sent word to his government on the terms of the meeting. ${ }^{41}$

That afternoon Elkins visited the White House to inform McKinley of the proposed armistice. The Senator also held discussions with Assistant Secretary of State William Rufus Day. ${ }^{42}$ When Elkins returned home he received word from Ireland that the Pope was pleased with the turn of events. The Pope also explained that he had telegraphed directly to the Queen Regent to encourage her influence to support the proposed armistice. Archbishop Ireland also told Elkins that he had discussed the

\footnotetext{
${ }^{40}$ Elkins’ Journal., West Virginia Collection., A\&M No. 2175. Box 4, p.4.

${ }^{41}$ Ibid., pp. 4-6.

42 Due to Sec. of State John Sherman's deteriorating mental condition, his assistant often performed his duties.
} 
situation with French Ambassador Jules Cambon. The Ambassador promised Ireland he would have an "earnest” talk with the Spanish Minister about granting an armistice and also send a letter to the French government requesting they bring all possible pressure to bear on Spain. Elkins reported this progress to a "good-spirited” McKinley and his cabinet in a secret meeting. McKinley also wished to relay this information to the Cuban Junta to ascertain if they would agree to these measures. Acting as a go-between, Elkins promised the President he would meet with the Cuban Junta the following day. ${ }^{43}$

But that night around midnight a message from the White House was sent to Elkins asking him to come see the President immediately. The President had received a message from Minister Stewart Woodford in Madrid suggesting that Spain was seriously considering granting an armistice with the condition that the United States withdraw their fleet from Key West, Florida. McKinley was adamantly opposed to any suggestion of removing the navy from Cuban waters. He knew that it would be political suicide if he made such an enormous concession to Spain as Congress would pounce on any sign of weakness. Word was sent back to Woodford that the United States' Navy would have to remain in Key West. ${ }^{44}$

The next morning, as promised, Elkins meet with an American Cuban Junta spokesman, Col. John J. McCook. Elkins bluntly told McCook that he appreciated the Cuban cause but it was impossible for the rebels to win Cuban recognition through war. Elkins explained that if war was declared on Spain the United States would insist on taking Cuba and Puerto Rico as a war indemnity. The only way for the rebels to achieve Cuban recognition, Elkins continued, was for the Spanish and Cuban rebels to agree to

\footnotetext{
${ }^{43}$ Elkins' Journal., A\&M No. 2175. Box 4, pp 6-9.

${ }^{44}$ Ibid., pp. 9-12.
} 
an armistice and then work for recognition through peaceful channels. McCook did not agree with Elkins but said he would discuss the matter with other representatives of the Junta. $^{45}$

On April 5, Elkins received word that his three-way negotiations with Archbishop Ireland and Spanish Minister Polo may have bore some fruit. The Pope had cabled the Archbishop a copy of a dispatch he received from the Queen Regent in which she signaled a willingness to cooperate with the Pontificate. In the message, the Queen Regent told the Pope she had "confided the honor of the Armies of Spain into his hands" and "would consent to an armistice." Elkins and the Archbishop understood this to mean the Spanish Crown was willing to let the Vatican negotiate a peaceful deal but Elkins needed official confirmation through the Spanish Minister. Elkins realized the Spanish government may hold a different opinion than the Queen Regent and the deal to grant an armistice may come with untenable conditions. ${ }^{46}$

Waiting for word from Madrid, Elkins went to the Senate to make the case to his fellow Senators why it was important to avoid granting recognition of Cuban independence. He explained to his colleagues that the Cubans had not earned their independence and if the United States was forced to go to war on account of the rebels America should keep Cuba, Puerto Rico and the Philippines to help pay war costs. Thereupon, he met with President McKinley and told him that members of the Senate were coming around to this idea. Later in the day, Elkins met once again with the Junta representative McCook and warned him that time was running out. Elkins reiterated the need for the rebels to accept an armistice and failing that, the United States would annex

\footnotetext{
${ }^{45}$ Ibid., p. 12.

${ }^{46}$ Ibid., pp. 12-17.
} 
Cuba and the island would be "lost to the insurgents forever." McCook reacted angrily to this threat and called McKinley "almost cruel" for wanting to deny the struggling people of Cuba their liberty. ${ }^{47}$

For several days after, Elkins traveled back and forth between the White House, the Archbishop's residence, the Spanish Minister's office and the Senate trying to broker a peaceful conclusion to the Cuban crisis. On April 7, McKinley told Elkins that the Spanish cabinet was fighting among themselves and that the proposed armistice had been scrapped. Elkins then conferred with Archbishop Ireland on Spain’s stubbornness and the decision was made to turn up the pressure on the Spanish Minister. The Archbishop visited Minister Polo later that day and gave him the most unadorned threat yet delivered. Ireland warned Polo that if his government failed to seek peace the United States would not only take Spain's honor they would also take Cuba, Puerto Rico, the Philippines and bombard Barcelona. And after this humiliation; “...the Jewish bondholders would simply devour Spain.” In taking his leave from Polo, the Archbishop promised that if the Spanish failed to give the Cubans an armistice Spain would cease to be a nation. ${ }^{48}$

The situation in Madrid was likewise becoming more agitated. The Pope had renewed his pressure on the Spanish government to suspend hostilities in Cuba and the Spanish Cabinet hotly debated what action to take. During one closed session of discussion, the American Minister, Woodford grew impatient and interrupted the meeting with a message that criticized the Spanish Cabinet members for delaying and asked them to make a final decision within six hours. This unpardonable act of

\footnotetext{
${ }^{47}$ Ibid., pp. 17-21.

${ }^{48}$ Ibid., pp. 21-30.
} 
indiscretion on the part of Woodford sent the Spanish government into a fury. They issued a condemnation of Woodford's action and brought all deliberations to a sudden halt. Elkins noted in his journal that; "it was too bad war might turn upon so insignificant a thing., ${ }^{49}$

During these final negotiations, Congress was becoming increasingly impatient for action. Several Democrats declared that it was now the sole responsibility of Congress to declare war and President McKinley’s position was irrelevant. ${ }^{50}$ Republican voices were also now heard loudly among the war cries. In a letter to the president, Henry Cabot Lodge described the growing martial spirit among his constituency and grimly predicted "if the war in Cuba drags on through the summer with nothing done we should go down in the greatest defeat ever known before the cry 'Why have you not settled the Cuban question?’,51

\footnotetext{
${ }^{49}$ Ibid., pp. 30-37.

50 “Congress Prepared To Act,” New York Times. 5 April 1898, p. 1.

${ }^{51}$ Lodge to McKinley, March 21, 1898. McKinley Papers. Reel 61.
} 


\section{Chapter Five}

\section{Decision for War}

Without any measure of success on the diplomatic front and faced with the threat of Congress taking the initiative on the Cuban issue, McKinley finally submitted his Declaration of War to Congress on April 11, 1898. This lengthy and legalistic document requested the authority to use the military to bring hostilities in Cuba to a close but did not exclude a peaceful resolution if possible. Conciliatory in tone, McKinley's message began by describing the intolerable conditions that existed in Cuba and addressed the adverse effects the ongoing hostilities were causing to American trade and investors. He spoke of the aroused emotions of the American people and legislators that interfered with his administration's advancement of domestic concerns. He meticulously listed the numerous diplomatic attempts that were made to solve the crisis peacefully. ${ }^{1}$

The war message also extended sympathy to the Cuban people but asserted that they would not be given a recognition of independence. The president considered recognition of Cuban independence as unnecessary for American intervention and unwarranted under international law. He also warned that recognition of any particular government in Cuba might subject the United States to embarrassing conditions of international obligation and "In case of intervention our conduct would be subject to the approval or disapproval of such government. We would be required to submit to its direction and to assume to it the mere relation of a friendly ally.” McKinley feared that if sovereignty were granted, American forces in Cuba would come under the jurisdiction

\footnotetext{
${ }^{1}$ McKinley’s Message to Congress, 11 April 1898, in Foreign Relations, 1898, 760.
} 
of the rebel commanders and the United States would lose the ability to demand reparations for damaged American property and investments that had occurred during the war. Instead, American forces would intervene only as a neutral power in order to terminate hostilities between Spain and the people of Cuba and allow for the establishment of a new government. ${ }^{2}$

McKinley’s war message handed the responsibility of further action against Spain over to the legislative body; “The issue is now with Congress...I have exhausted every effort to relieve the intolerable condition of affairs which is at our doors... I await your action.” In conclusion, McKinley offered one last bit of hope that peace could be achieved without military intervention. He reported that the day before he had finally received information that the Queen Regent of Spain had ordered General Blanco to suspend all hostilities on the island. He recommended that Congress give this royal decree solemn consideration in their deliberations and added; "If this measure attains a successful result, then our aspirations as a Christian, peace-loving people will be realized."3

Initial reactions to McKinley’s message were, as to be expected, mostly divided among party lines. The majority of Republicans embraced the message as a thoughtfully constructed statement that demonstrated the president's statesmanship. "I consider it a strong and patriotic utterance, fully covering the whole question and justifying the confidence of the people of the United States everywhere have in the executive,” declared Iowa Republican Senator Jonathan Dolliver. Continuing, he suggested that members of Congress should accept McKinley’s recommendations. In concurrence,

\footnotetext{
${ }^{2}$ Ibid.

${ }^{3}$ Ibid.
} 
Senator Elkins told reporters that McKinley had made the case admirably and assured them that the people of America and Congress would indeed sustain the message. Illinois Republican member of the Foreign Relations Committee, Shelby M. Cullom, agreed with Elkins that the President's words would carry great influence but suggested that the Senate may go further than he had recommended. ${ }^{4}$

Leaders of the opposition parties were unimpressed with McKinley's message and responded angrily. Their primary criticism centered around the president's failure to declare Cuba's independence or call for immediate armed intervention on behalf of the Cubans. Moreover, they derided the message as intentionally confusing and offering more problems than solutions. ${ }^{5}$ Missouri Democrat Congressman Alex M. Dockery ridiculed the message as anemic and "suggestive only of vague, uncertain, and hesitating policies.” South Carolina Democrat Benjamin Tillman called it "illogical and inadequate.” Kansas Populist Congressman Jerry Simpson claimed that the message was "weak and vacillating" and a reflection of the man who gave it. He also declared that McKinley's proposal was humiliating and would go down in history as having deprived America of her manhood and love of freedom. ${ }^{6}$

Representatives of the Cuban Junta were equally disappointed in the President's message. Official spokesmen for the organization refused to openly discuss the matter, but off the record expressed disgust with the implications of the message. Unidentified Junta members vented to reporters that the McKinley administration had walked into a diplomatic trap set by the Spaniards. The Junta members reasoned that since Spain had agreed to a suspension of hostilities, McKinley would be restrained from taking any

4 “Comment On The Message,” New York Times. 12 April 1898, p. 2.

5 “An Angry Congress,” New York Times. 12 April 1898. p. 1

6 “Comment On The Message,” New York Times. 12 April 1898, p. 2. 
military action against them. However, since McKinley's message had called for forcible intervention to constrain both sides in the conflict, the American guns would now be aimed at the insurgents. McKinley had effectively aligned the United States with Spain and the Cubans would continue their fight for independence regardless of who the enemy was. The Junta also warned that if indeed the American military took action against the Cubans, it would be the "death knell” for the McKinley administration and the Republican Party. ${ }^{7}$ Evidently, the Junta believed the majority of Americans were sympathetic to the Cuban cause and if McKinley waged war on the rebels, the American electorate would hold the president and his party responsible in the next election.

Across the Atlantic, Spain had a very different interpretation of McKinley's war message. Sagasta's government considered the message an insult to Spain's dignity and issued an official statement that repudiated the United States’ claim to have legal authority to intervene in Spanish territory. The Madrid periodical El Correo argued that Washington’s “lamentations over Cuban misfortunes” were hypocritical since the American people and members of government were responsible for supporting the rebels and thus prolonging the war. The Conservative Party organ, El Epoca assailed McKinley for ignoring Spanish sacrifices made in agreeing to a cease fire. El lleraldo de Madrid went even further in their condemnation of McKinley, announcing that the message had revealed that the United States was the true enemy and "the author of the war, who has taken advantage of the honesty of Spanish diplomats...” The paper went on to declare that all diplomatic avenues were now closed and predicted that America

\footnotetext{
7 “Views of Junta Members,” New York Times. 12 April 1898, p. 2.
} 
would pay dearly for its blunder. ${ }^{8}$ Another Madrid paper, El Imparcial urged the people to unite and demand the navy be sent immediately to Cuban waters. Spanish citizens crowded the streets in patriotic demonstrations in Barcelona and Valencia shouting; “Long Live Spain!” Long live the army!” Long live Cuba!” ${ }^{9}$ On April 13, Spanish Minister Woodford telegraphed Secretary Sherman that American citizens were coming into various consulates seeking transportation out of the country and asked for instructions on how to deal with them. ${ }^{10}$

If McKinley had hoped his message would bring Spain and Cuba to the negotiating table he was mistaken. The threat of military action against the Spanish military and non-recognition of the insurgents only succeeded in inflaming the situation. The Sagasta government and the Queen Regent understood that the Spanish public would not tolerate additional humiliating concessions. A military defeat at the hand of the United States would be more honorable and politically viable than either losing to Cuban rebels or sheepishly accepting America's terms. The Cubans, for their part, were as recalcitrant as ever in their demand for complete independence; too much blood had been shed to settle for less. Besides, McKinley's message still had to go through Congress before the official policy on Cuba was formalized and the insurgents had many allies in Washington.

It is also possible that McKinley had intentionally loaded his message with ambiguous language in order to set off a long drawn-out debate in Congress. With Congressmen engaged in political warfare over the details of the message, McKinley's administration could have some breathing room to solve the crisis peacefully. Spanish

\footnotetext{
8 “Madrid Press Comments,” New York Times. 14 April 1898, p. 1.

9 “The Message In Madrid,” New York Times. 13 April 1898, p. 3.

${ }^{10}$ Woodford to Sherman. 13 April 1898, in Foreign Relations of the United States, 1898, 760.
} 
Minister Woodford floated the idea of a Cuban plebiscite and American diplomats began putting a proposal together but time was running out. Both Woodford and the Secretary of the Navy, John D. Long expressed their belief that with more time McKinley could have broke the impasse without bloodshed. ${ }^{11}$

However, in all likelihood the President knew that war was now unavoidable and hoped that calling for war would unite a divided country and lessen partisan bickering. McKinley was also relieved to finally pass the burden onto Congress. The last months had been agonizing for McKinley. He had suffered public ridicule through personal letters, opinion columns and cartoons lampooning him as weak and a coward. In demonstrations, rowdy crowds had even burned his likeness in effigy. ${ }^{12}$ Some in the business community still urged him to resist war but the list of his supporters was daily growing shorter. Those around him commented on the dark mood that enveloped the president and noticed the "haggard" look on his aging face. During a musical program being held in the White House in late March, McKinley had retired to a back room where he sat on a sofa and burst into tears. In an unusually candid conversation, McKinley confessed to journalist H.H. Kohlsaat that the constant political attacks were causing him sleepless nights and physical strain. ${ }^{13}$ On the day the message was delivered to Congress, an exhausted McKinley enjoyed his first evening of genuine

\footnotetext{
${ }^{11}$ John L Offner, An Unwanted War (Chapel Hill, N.C.: University of North Carolina Press, 1992), 190.

${ }^{12}$ Stanley Karnow, In Our Image: America's Empire in the Philippines. (New York, N.Y.: Random House, 1989), 96.

${ }^{13}$ Margaret Leech, In the Days of McKinley (New York, N.Y.: Harper \& Brothers, 1959), pp. 181-182., Stanley Karnow, In Our Image: America's Empire in the Philippines. (New York, N.Y.: Random House, 1989), 98.
} 
relaxation in weeks surrounded by several personal friends who kept their conversation “purely social.”14

In Congress, McKinley’s message was acted on quickly. On April 13, the Republican-chaired Foreign Affairs Committee brought to the full House a joint resolution that closely adhered to McKinley’s recommendations. The resolution authorized the President to use the military in Cuba but did not preclude non-military intervention. It also did not recognize either a Cuban Republic or independence for the Cuban people. But before the resolution could be read an argument erupted over the time allotted for debating the measure. The President's supporters in the House feared this final round of debates would provide the opposition with the opportunity to deliver lengthy harangues against McKinley and the Republicans. So accordingly, they limited the debate to forty minutes. Democrats bristled over this parliamentary maneuver and interrupted the proceedings to press for an extension of the debate. Texas Democrat Joseph Bailey arose in protest and requested that a Democratic substitute resolution be read. This minority resolution was similar to the one proposed except it recognized the “Republic of Cuba” and demanded the president to immediately send the United States’ military to remove Spanish forces. Speaker of the House Reed denied the motion amid boisterous cries of protests from the Democrats. Excited by the rowdy Democrats cheering him on, Bailey loudly exclaimed; "The Chair is trying to force the minority..,” before his voice was drowned out by Speaker Reed's gavel and shouts of “regular order!”15

\footnotetext{
14 “The President Much Relieved,” New York Times. 12 April 1898.

15 "Blows Averted in the House," New York Times. 14 April 1898, p.2.
} 
This was the final straw for the frustrated Democrats. They rose en masse to demand their voices be heard. James Richardson of Tennessee shouted "They [the Republicans] are simply playing for political advantage and the people of the country ought to know it!” The Republicans responded in kind and the opposing parties began shouting remonstrations at each other across the aisle. The verbal jousting soon turned violent when a Republican, Charles Brumm accused Democrat Franklin Bartlett of being a liar. The latter picked up a large bound copy of the Congressional Record and hurled it at his accuser. The two antagonists lunged at each other and chaos ensued. Members of each side collided in the middle of the room as they struggled to hold back the combatants. Women seated in the galleries screamed as innocent bystanders scrambled to escape the melee. A government employee caught in the middle of the confusion was knocked down from a blow to his jaw. Banging his gavel, Speaker Reed ordered the Sergeant of Arms, to restore order. Fearing for their safety, the House Rules Committee retired for a special meeting to reconsider the parameters of the debate: thus ended the first attempt to pass a resolution on the president's message. ${ }^{16}$ Faced with the most critical question confronting the American people since the Civil War, congressmen resorted to slinging insults and fists to resolve their differences.

The House Rules Committee returned minutes later and each side was allowed to offer their resolutions and debate their positions. Debate on the resolutions was on par with the many preceding confrontations in Congress over the Cuban situation. Republicans defended their position of pursuing every possibility of peace before war was declared. Cuban recognition was argued against on legal grounds and the Democratic Party was chastised for exploiting a national crisis to score political points.

${ }^{16}$ Ibid. 
Speaking for the other side, the leading Democratic member of the Foreign Affairs Committee, Hugh A. Dinsmore commented in a reflective tone that he regretted the manifestation of partisanship that had occurred earlier. "If there was ever a period in the history of this government when patriotic dignity should have been shown and partisanship should have been subordinated to statesmanship that period is now," he declared before a prolonged round of applause. Having prefaced his speech with praise for bi-partisanship, Dinsmore proceeded to blame the hesitating policies of the majority party for the death of the sailors on board the USS Maine. Speeches by other Democrats in the House continued the narrative that McKinley and his supporters were responsible for the tragedy in Havana harbor and the continued suffering of innocent Cubans.

The acting chairman of the committee, Republican Robert Adams closed the debate by calling for unity among all members of the House regardless of party affiliation. He touted the Republican-sponsored resolution as sufficient to ensure America’s Christian duty toward the Cubans and maintain the nation's honor. In conclusion he appealed to the House; "that one and all rise in their places and cast their votes to show the world... that however we differ on matters of detail, we are Americans one and all, and that politics cease at the seacoast.” The minority resolution was voted on first and defeated by 191 nays to 148 yeas. The majority resolution was then offered and despite the many voices that had ridiculed it earlier it easily passed by 325 yeas to 19 nays, with 12 members not voting. ${ }^{17}$

\footnotetext{
${ }^{17}$ U.S., Congress, House, Congressional Record, 55th Cong., 2nd sess., 1898, 31, pt.3: 3817-3821.
} 
In the Senate, the deliberations on McKinley's message were less dramatic if no less partisan. ${ }^{18}$ The debate in the upper chamber lasted four days with thirty Senators speaking on several resolutions. In the end, the resolution they passed by a 51 to 37 margin, was similar to the House version except it included the Turpie-Foraker Amendment that recognized the "Republic of Cuba" and the Teller Amendment that disclaimed any American imperialist design on Cuba. ${ }^{19}$ Although most Republicans opposed the bill because of these two amendments, eleven of them defected to the other side. The House initially rejected the Senate resolution outright as well, but through a compromise the Turpie-Foraker Amendment was dropped and the Teller amendment adopted.

Shortly afterward the resolution was signed by McKinley, an ultimatum that required Spain to vacate Cuba was hand carried by Secretary of State Day to the Spanish Ambassador. With war unavoidable, McKinley’s administration favored taking swift and decisive actions against Spain. Previously instructed by McKinley, war planners from the Naval Academy had completed a contingency plan which included attacking the Spanish navy in the Caribbean as well as in the Pacific. Like Cuba, the Philippine islands were also engaged in an insurrection against the Spanish and American intervention would be needed to end the hostilities. On April 21, McKinley ordered a blockade of all Cuban ports and on April 24, Commodore George Dewey, commander

\footnotetext{
${ }^{18}$ There was one minor incident where Congressman Money called Congressman Wellington a liar. However, Money quickly apologized and the tension was diffused.

${ }^{19}$ U.S., Senate, Congressional Record, 55th Cong., 2nd sess., 1898, 31, pt.3: 3988-3993., This amendment named after its author Senator Henry Moore Teller, a Silver Republican from Colorado more specifically stated, “ The United States of America hereby disclaims any disposition of intention to exercise sovereignty, jurisdiction, or control over said island except for pacification thereof, and asserts its determination, when that is accomplished, to leave the government and control of the island to its people."
} 
of the Asiatic squadron, was ordered to proceed to the Philippines to destroy the Spanish fleet. $^{20}$

The prospect of war was an exciting enterprise for the American nation. Treated as a sort of coming of age party, thousands of men and women, from nearly every section and demographic of the United States, clamored to offer their services for the war effort. Newspapers reported that Southerners were ready to stand shoulder to shoulder with their former Northern foes in defense of their now-united country. Recent immigrants to America, likewise, declared their eagerness to prove their loyalty to their new home on the battlefield. ${ }^{21}$ Similarly patriotic, 10,000 African-Americans volunteered and were formed into all-black units. ${ }^{22}$ Even, Annie Oakley, of Buffalo Bill's Wild West Show fame, wrote McKinley a letter offering to form a company of fifty women sharpshooters to fight Spain. ${ }^{23}$

Many politicians were anxious to join the action as well. Theodore Roosevelt resigned from his post as Assistant Secretary of the Navy and formed his own regiment, the "Rough Riders."24 Not to be outdone, William Jennings Bryan organized his own regiment of Nebraskan volunteers and headed for Florida to wait for transportation to Cuba. $^{25}$ In an effort to heal Civil War wounds, President McKinley appointed several ex-Confederate officers to lead the United States’ Army. One of these newly-appointed

\footnotetext{
${ }^{20}$ Margaret Leech, In the Days of McKinley (New York, N.Y.: Harper \& Brothers, 1959), pp. 185-187.

21 “Volunteer Reserve Rush,” New York Times. 24 April 1898, p. 1.

${ }^{22}$ Donald H. Dyal, Historical Dictionary of the Spanish American War (Westport, CT.: Greenwood Publishing Group, Inc., 1996), p. 43.

23“"Letter to President William McKinley from Annie Oakley,” (300369) [Electronic Records]; Old Military and Civil Records LICON, Textual Archives Service Division (NWCTB), National Archives Building at $7^{\text {th }}$ and Pennsylvania Avenue NW, Washington, DC

${ }^{24}$ Donald H. Dyal, Historical Dictionary of the Spanish American War (Westport, CT.: Greenwood Publishing Group, Inc., 1996), pp. 283-284.

${ }^{25}$ Williams Jennings Bryan, Memoirs of Williams Jennings Bryan (New York N.Y.: Doubleday and McClure, 1925), 273, 275.
} 
Generals was the sixty-one year old Alabama Congressman Joseph Wheeler. ${ }^{26}$

Obviously, the McKinley administration maintained a tight control over who was allowed to participate in the war. McKinley, the perennial politician, understood well the danger of offering his political enemies the chance to win hero status in a war: Bryan spent the war on the coast of Florida commanding a makeshift army camp.

The war itself was a quick lopsided victory for the United States. The first battle of the war took place in Manila Bay, where Commodore Dewey's fleet defeated a Spanish squadron in a matter of hours (Apparently, word of this action was the first time many in Congress had heard of the Navy's intention of conducting operations in the Pacific).${ }^{27}$ In the Caribbean theatre of war, the American forces had similar successes. Besides some stiff resistance by the Spanish in Cuba, and almost no resistance in Puerto Rico, the war was over in 113 days. ${ }^{28}$ Afterwards, the United States had acquired an extensive overseas empire. On December 10, 1898, representatives of the United States and the Spanish government met to sign the Treaty of Paris, which required Spain to finally relinquish sovereignty over Cuba. The treaty also ceded Puerto Rico, Guam and (for $\$ 20$ million dollars) the Philippines to the United States for guardianship. ${ }^{29}$

Although American members of the peace delegation agreed to the treaty, ratification by a two-thirds margin in the U.S. Senate was required to bring the treaty into law. Obtaining Democratic support for this treaty would prove a difficult task for

\footnotetext{
${ }^{26}$ Margaret Leech, In the Days of McKinley (New York, N.Y.: Harper \& Brothers, 1959), p.229.; With snow white hair and beard, Wheeler was noticeably thin and frail. While in the heat of battle in Cuba, an excited and confused Wheeler was reported to have shouted to his men, "We've got the damn Yankees on the run!"

${ }^{27}$ It is noteworthy that during the long congressional debate leading up to the war with Spain, the Philippines were rarely, if ever, mentioned.

${ }^{28}$ Margaret Leech, In the Days of McKinley (New York, N.Y.: Harper \& Brothers, 1959), pp. 241-291.

${ }^{29}$ Donald H. Dyal, Historical Dictionary of the Spanish American War (Westport, CT.: Greenwood Publishing Group, Inc., 1996), 253-254.
} 
the McKinley administration in the months ahead. McKinley believed that keeping the islands would benefit both the United States and the native inhabitants. Concerning the Philippines, McKinley sought the advice of John Forman, who was the leading Filipino authority at the time. Forman warned that the Filipinos were divided along racial lines and that if the country were abandoned it would descend into chaos and bloodshed. McKinley also realized that other countries would likely intervene if America left. Germany had already been negotiating with Spain to purchase the Philippines; in this regard, on June 12, a German squadron under Admiral Otto von Diederichs had arrived in Manila harbor. ${ }^{30}$

The debate in the Senate on ratification of the treaty also focused mainly on the annexation of the Philippines. Despite the unifying, nationalistic event of victory in war, partisan division remained intense. These heated exchanges among the Democrats and Republicans revealed that the parties were as divided as ever. Democrats once again argued against the treaty on racial grounds. Senator Tillman summed up their ideology shortly after the vote in February of 1899, “...with five exceptions every man in this Chamber who has had to deal with the colored race in this country voted against the ratification of the treaty. It was not because we are Democrats, but because we understand and realize what it is to have two races side by side that can not mix or mingle without deterioration and injury to both and the ultimate destruction of the civilization of the higher." 31 It is ironic that the Democratic congressmen who pushed

\footnotetext{
${ }^{30}$ Margaret Leech, In the Days of McKinley (New York, N.Y.: Harper \& Brothers, 1959), 325328.; Donald H. Dyal, Historical Dictionary of the Spanish American War (Westport, CT.: Greenwood Publishing Group, Inc., 1996), 106-108.

${ }^{31}$ U.S., Congress, Senate, Congressional Record, 55th Cong., 3rd sess., 1899, 32, pt.6: 1532.
} 
the hardest for war with Spain now protested the loudest against the American expansion that resulted.

All but two of the Republican Senators supported the treaty. Their stated reasons for ratification varied. Some declared it was now America's responsibility to bring democracy and education to these suppressed people. Others discussed the economic benefits of an overseas empire for the United States and the islands' inhabitants. Others argued that America’s reputation as a world power was at stake. The two Republican Senators who voted against the treaty, George Hoar and Eugene Hale, argued that this form of imperialism was against American principles. Hoar warned his colleagues in the Senate, “This Treaty will make us a vulgar, commonplace empire, controlling subject races and vassal states, in which one class must forever rule and other classes must forever obey."32

As the vote on the treaty approached, McKinley’s Republican allies in the Senate worked overtime buttonholing Democrat members and making cloakroom deals for their vote. Nonetheless, a preliminary headcount revealed that the treaty was still four or five votes short of ratification. McKinley, however, found support from an unlikely source. Democratic leader William Jennings Bryan visited the capitol shortly before the vote and urged his supporters to vote for the treaty. In Bryan’s truly Machiavellian scheme, he planned on using anti-imperialism as a campaign issue in the next presidential election. $^{33}$ The treaty was approved on February 6, 1899 by a vote of 57 to 27; only one

\footnotetext{
${ }^{32}$ Robert L. Beisner, Twelve Against Empire: The Anti-Imperialists, 1898-1900 (New York N.Y.: McGraw-Hill, 1968), p.152.

${ }^{33}$ William Jennings Bryan became an outspoken critic of McKinley and Roosevelt’s foreign policy that he labeled "wars of conquest.” However, as Woodrow Wilson's Secretary of State, Bryan helped establish a military dictatorship in Haiti and sent the U.S. military to Mexico and the Dominican Republic.
} 
vote more than the two-thirds majority required. ${ }^{34}$ Once again, politics had played a crucial role in shaping America's foreign policy.

${ }^{34}$ Margaret Leech, In the Days of McKinley (New York, N.Y.: Harper \& Brothers, 1959), 354. 


\section{Conclusion}

In the final analysis, the road to the "splendid little war" of 1898 was paved with politics. Beginning with an unpopular Cleveland presidency and an unprecedented economic crisis, congressmen found it advantageous to redirect the voter's anger toward Spanish atrocities in Cuba. Once McKinley came into office, and persuaded the jingoes in his own party to abandon the war cry, the Cuban issue became bitterly partisan. In this poisoned environment, there was no chance for an honest debate on the issue. Exagerated rhetoric by irresponsible politicians forced the United States ever closer to war and made any diplomatic solution impossible. President McKinley at first tried for a negotiated end to the Cuban dispute. However, as the options for ending the dispute peacefully proved ineffective, McKinley chose to declare war. The President thought a declaration of war (and war itself) would curtail partisan division in Congress but that did not prove to be the case.

All political parties had played a game of political expediency that accelerated the U.S. entrance into global affairs and would set the stage for further conflicts in the twentieth century. As unprecedented as this episode in American history was, it was not to be an isolated incident. Throughout the twentieth century, American foreign policy continued to be framed by partisan politics. From the First World War to the Cold War, American politicians have exploited or even aggravated foreign dilemmas for partisan or personal gain. The celebrated tradition of politics ending “at the water's edge” is more of a myth than reality. As America enters the twenty-first century and faces new challenges from abroad, the political parties are as divided and indisposed to cooperation 
as ever. Hopefully in the future, American politicians can put aside their ambitions to serve the best interests of the nation. 


\title{
Bibliography
}

\section{Primary Sources:}

\section{Personal Letters and Journals}

Elkins’ Journal

The Cleveland Papers

The McKinley Papers

The Stephen B. Elkins Papers

\author{
Newspapers and Magazines \\ Fairmont Free Press \\ New York Times \\ North American Review \\ The Atlantic Monthly \\ The World \\ Wall Street Journal
}

\section{Government Sources}

U.S., Congress, Senate, Congressional Record, 53rd Cong., 2nd sess., 1895, 27, pt.3.

U.S., Congress, Senate, Congressional Record, 53rd Cong., 3rd sess., 1895, 27, pt.4.

U.S., Congress, Senate, Congressional Record, 54th Cong., 1st sess., 1895, 28, pt.1.

U.S., Congress, Senate, Congressional Record, 54th Cong., 1st sess., 1896, 28, pt.2. 
U.S., Congress, Senate, Congressional Record, 54th Cong., 1st sess., 1896, 28, pt.4.

U.S., Congress, Senate, Congressional Record, 54th Cong., 2nd sess., 1896, 29, pt.1.

U.S., Congress, House, Congressional Record, 55th Cong., 2nd sess., 1897, 31, pt.1.

U.S., Congress, House, Congressional Record, 55th Cong., 2nd sess., 1897, 31, pt.3.

U.S., Congress, Senate, Congressional Record, 55th Cong., 3rd sess., 1898, 31, pt.4.

U.S., Congress, House, Congressional Record, 56th Cong., 2nd sess., 1899, 33, pt.6.

U.S., Department of State, Foreign Relations of The United States, Government Documents Series, no. 392480 (1895)

U.S., Department of State, Foreign Relations of The United States, Government Documents Series, no. 915 (1896)

U.S., Department of State, Foreign Relations of The United States, Government Document Series, no. 4 and 24 (1897)

Facsimile of Letter Written by the Spanish Minister Enrique Dupuy de Lôme letter to José Canalejas (Record Group 59) [Electronic Records]; Notes from the Spanish Legation in the U. S to the Department of State, 1790-1906, LICON, Textual Archives Service Division (NWCTB), National Archives Building at $7^{\text {th }}$ and Pennsylvania Avenue NW, Washington, DC.

http://www.archives.gov/historical-docs/todays-doc/index.html ?dod-date $=209$

Letter to President William McKinley from Annie Oakley (300369) [Electronic Records]; Old Military and Civil Records LICON, Textual Archives Service Division (NWCTB), National Archives Building at $7^{\text {th }}$ and Pennsylvania Avenue NW, Washington, DC http://www.archives.gov/press/press-releases/1999/nr99-15.html

The Annals of America: Primary Sources of American History 1895-1904., Encyclopedia Britannica, Inc., 1976. 


\section{Secondary Sources:}

\section{Books}

Beisner,Robert L. From the Old Diplomacy to the New: 1865-1900 (Arlington Heights, Il..: Harlan Davidson, Inc., 1986

Beisner, Robert L. Twelve Against Empire: The Anti-Imperialists, 1898-1900.

New York N.Y.: McGraw-Hill, 1968.

Brands,H.W. Andrew Jackson: His Life and Times. New York, N.Y.: Anchor Books, 2006.

Brands, H.W. The Reckless Decade: America in the 1890s Chicago, Il.:University of Chicago Press, Ltd., 1995.

Bryan, Williams Jennings. Memoirs of Williams Jennings Bryan. New York N.Y.: Doubleday and McClure, 1925.

Carr, Albert Z. John D. Rockefeller's Secret Weapon. New York, N.Y.: McGrawHill Book Company Inc., 1979.

Dyal, Donald H. Historical Dictionary of the Spanish American War. Westport, CT.: Greenwood Publishing Group, Inc., 1996.

Fry, Joseph A. "Phases of Empire: Late Nineteenth-Century U.S. Foreign Relations," In The Gilded Age: Perspectives on the Origins of Modern America, edited by Charles Calhoun. Lanham, MD: Rowan \& Littlefield Publishers, Inc., 2006.

Greenberg, Amy S. Manifest Manhood and the Antebellum American Empire. New York, NY.: Cambridge University Press, 2005.

Hamilton, Richard F. President McKinley, War and Empire. New Brunswick, N.J.: Transaction Publishers, 2006.

Hoganson, Kristin L. Fighting for American Manhood: How Gender Politics Provoked the Spanish-American and Philippine-American Wars. New Haven, CT.: Yale University Press, 1998.

Jackson, Stanley J.P. Morgan: A Biography. Briarcliff Manor, N.Y.: Stein and Day Publishers, 1983.

Karp, Walter. The Politics of War. New York, N.Y.: Harper \& Row, 1979. 
LaFeber, Walter. The New Empire: An Interpretation of American Expansion 1860-1898. Ithaca, New York, N.Y.: Cornell University Press, 1963.

Lambert, Oscar Doane. Stephen Benton Elkins. Pittsburgh, PA.: University of Pittsburgh, 1955.

Leech, Margaret. In the Days of McKinley. New York, N.Y.: Harper \& Brothers, 1959.

Lindsey, Almont The Pullman Strike. Chicago, Il.: University of Chicago Press, 1942.

Lodge, Henry Cabot The War with Spain, New York, N.Y.: Harper \& Brothers, 1899.

Logan, Rayford W.. The Betrayal of the Negro, from Rutherford B. Hayes to Woodrow Wilson. New York N.Y.: Da Capo Press, 1965.

May, Ernest R. Imperial Democracy: The Emergence of America as a Great

Power. $\quad$ Chicago: Imprint Publications, 1991.

McGerr, Michael E. The Decline of Popular Politics. New York, N.Y.: Oxford University Press, 1986.

McKinley, William. Speeches and Addresses of William McKinley from March $\underline{1,1897}$ to May 30, 1900. New York N.Y.: Doubleday and McClure, 1900.

McPherson, James M. “To the Best of My Ability.” London, U.K.: DK Publishing, Inc., 2004.

Nevins, Allan. Hamilton Fish: The Inner History of the Grant Administration Binghamton, N.Y.: Vail-Ballou, Inc., 1936.

Nichols, Franklin. Franklin Pierce: Young Hickory of the Granite Hills.

Philadelphia, PA.: University of Pennsylvania Press, 1969.

Offner, John L. An Unwanted War. Chapel Hill, N.C.: University of North Carolina Press, 1992.

O’Toole, G.J.A. The Spanish War: An American Epic 1898. (New York, NY., W.W. Norton \& Company Inc, 1984),

Pérez , Louis A., Jr.. The war of 1898: the United States and Cuba in History and Press,1998. Historiography. Chapel Hill, N.C. : University of North Carolina 
Strouse, Jean Morgan: American Financier. New York, N.Y., Random House, 1999.

Swanberg, W.A. Pulitzer. New York, N.Y.: Charles Scribner’s Sons, 1967.

Vincent, Henry., Mass Violence in America: The Story of the Commonweal. NY, New York.: Arno Press Inc., 1969.

Wheelan, Joseph Invading Mexico: America's Continental Dream and the Mexican War, 1846-1848. New York, N.Y.: Carroll \& Graf Publishers, 2007.

Welch, Richard E. The Presidencies of Grover Cleveland. Lawrence, KS.:

University Press of Kansas, 1988.

Wilkerson, Marcus M. Public Opinion and the Spanish-American War. New York, NY.: $\quad$ Antheneum House Inc., 1932.

\section{Articles}

Baylen, Joseph O. and John Hammond Moore. "Senator John Tyler Morgan and Negro Colonization in the Philippines, 1901 to 1902.” Phylon Journal (1 ${ }^{\text {st }}$ Qtr. 1968) Vol. 29, No. 1: 65-66.

Romer, Christina. "Spurious Volatility in Historical Unemployment Data." Journal of $\quad$ Political Economy 19 ( November 1986) : 1-37.

\section{Electronic Sources}

Modern History Sourcebook: United States-Spain: Treaty of 1819.

http://www.fordham.edu/halsall/mod/1819florida.html (1998). 